\title{
A 200 éves német nyelvű tanítóképzés története Magyarországon
}

\author{
Márkus Éva* - M. PintérTibor ** \\ * az Eötvös Loránd Tudományegyetem Tanító- és Óvóképző Karának egyetemi docense \\ markuse@caesar.elte.hu \\ ** a Károli Gáspár Református Egyetem Bölcsészet- és Társadalomtudományi Karának \\ egyetemi adjunktusa \\ m.pinter.tibor@kre.hu \\ A tanulmány a magyarországi német nyelvü, illetve német nemzetiségi tanitóképzés be- \\ mutatására fókuszálva foglalkozik az első magyarországi önálló tanítóképző intézet po- \\ litikai és nyelvi fordulatok között formálódó belső életével, valamint részletesen bemu- \\ tatja a történelmi Magyarország, és a 20. század német nyelvü tanitóképzésének történe- \\ tét. A tanulmány elsősorban hazai és külföldi forrásmunkákra alapozva tekinti át a \\ magyarországi német nyelvü tanitóképzés első 200 évét, miközben kvalitatív és kvantita- \\ tív adatokra támaszkodva teszi egyértelmüvé, hogy a német nyelvü és nemzetiségi taní- \\ tóképzés évszázadok óta szerves része a hazai oktatásügynek.
}

Kulcsszavak: nemzetiségi tanitóképzés, német nyelvü tanítóképzés, állami tanitóképzés, Szepeskáptalan, oktatáspolitika

DOI: 10.37205/TEL-hun.2019.1-2.04

\section{Bevezető}

A tanulmány megemlékezik a 2019-ben 200. évfordulóját ünneplő magyar tanítóképzésről, felidézi az első önálló magyarországi képzőintézet történetét, amely nem magyar nyelvü volt. Az oktatás nyelve a német és szlovák volt, így az évforduló egybeesik a német tannyelvű tanítóképzés kezdetével is.

A tanulmány forrásait korábbi, magyar és idegen nyelvű történeti munkák adják, a szerzők ezek szintetizálására törekedtek. Az írás célja történeti áttekintést nyújtani a német tannyelvü tanítóképzés magyarországi két évszázadáról: bemutatni a képzőhelyeket, a képzés körülményeit, struktúráját, a tannyelvet, valamint az oktatott tantárgyakat. A tanulmányban, különösen annak második felében, a szerzők statisztikai adatok felhasználásával igyekeztek érthetőbbé és „kerekebbé” tenni a magyarországi német nyelvű képzés bemutatását. 


\section{Nemzetiségi tanítóképzés vagy német nyelvű tanítóképzés?}

A Pedagógiai lexikon szerint (Báthory - Falus, 1997) szerint nemzetiségi oktatás alatt a XX. század végén a nemzetiségi tanulók számára létesített intézményes nevelés-oktatást értettük, amelynek feladata, hogy szervezetten biztosítsa a nemzetiségi nyelv tanulását, a nemzetiségi történelem, kultúra, hagyomány megismerését a közösségi identitástudat megörzése, ápolása, erősítése mellett. A sajátos célok és követelmények teljesítéséhez, a müködés feltételeihez az állam emelt normatív támogatást nyújtott és nyújt (Báthory - Falus, 1997). Demeter szerint nemzetiségi pedagógus az a pedagógus (óvónő, tanító, tanár), aki nemzetiségi pedagógusképzésben részesült, nemzetiségi végzettséggel rendelkezik és/vagy nemzetiségi hovatartozású, nemzetiség nyelvét beszélő, nemzetiségi oktatási programokban foglalkoztatott (Báthory - Falus, 1997).

A nemzetiségi tanítóképzés tehát alapvetően különbözik a német tannyelvü tanítóképzéstől, és XX. század végi fejlemény hazánkban. Ennek megfelelően jelen tanulmány alapvetően a német tanítási nyelvű tanítóképzés a történetét tekinti át, és csak a tanulmány végén foglalkozik a fenti definíció szerint vett nemzetiségi tanítóképzésse ${ }^{24}$. Ugyanakkor 200 éve még természetes volt, hogy a nemzetiségek lakta területen élők Magyarországon saját anyanyelvükön részesülhettek alsófokú oktatásban, így a tanítóképzők is erre készítették fel a diákokat. Tehát nem pusztán német nyelvủ oktatásról beszélünk, hanem a nemzetiségekhez szorosan kötődő tanító képzésről, hiszen számukra a német volt az anyanyelv. Nekik szólt, tehát ebben a tekintetben rokon a mai nemzetiségi oktatással, bár az állam csak 1937 óta tekinti feladatának a tanítók e célból történő képzését. 1937-ig ezt egyházi képzők látták $\mathrm{el}^{25}$ (Donáth, 2018).

\section{A tanítási nyelv kérdése a tanítóképzésben a kezdetektöl a kiegyezésig}

A 200 évvel ezelőtti társadalmi, politikai viszonyok által alakított oktatási helyzet jelentősen eltért a maitól. Ennek megfelelően az első magyarországi tanítóképzők egyházi alapításúak voltak. A XX. század kezdetéig a nemzetiségi hovatartozás (így az oktatást érintő kérdések is) jellemzően szorosan összefüggött a felekezeti hovatartozás kérdésével (vö. Rácz Fodor, 1993), azonban a felekezet és nemzetiségi

\footnotetext{
${ }^{24}$ A nemzetiségi német tanárképzés jellemzőiről lásd bővebben Müller, 2015. 116-127. o. és Knipf-Komlósi - Müller, 2018. 64-66. o.

${ }^{25}$ „Kevéssé ismert tény, de igaz, hogy akkoriban (1937-ig) a magyar állam nem tartotta feladatának, hogy a történelmi, majd a trianoni Magyarország nemzetiségei számára anyanyelvi tanítóképzést nyújtó intézményeket tartson fenn. Így ez, ill. a kétnyelvü képzés az egyházi intézményekre hárult, némi állami segítséggel" (Donáth, 2018. 13. o.).
} 
kapcsolat nyomai mind a mai napig megmaradtak a történelmi Magyarország területén. ${ }^{26} \mathrm{Az}$ állami tanítóképzés létrejöttét az 1868-as népoktatási törvény rendelkezései szabályozták (Rácz Fodor, 1993), míg az egyházakhoz, és rajtuk keresztül a nem magyar nyelvü nemzetiségi csoportokhoz kötődő tanítóképzés jóval előbb kezdődött. A német kisebbség életében ennek alapja, hogy esetében azonban problémásabb volt a helyzet, mivel tanítói - a népoktatási törvény bevezetése idején - gyakran képesítés nélkül tanítottak. Az erdélyi evangélikusok a XVI. századtól müködtettek tanítóik képzésére a papneveldékhez kapcsolódó „teologiaipaedagogiai szeminarium”-okat, a leghíresebbeket Medgyesen (1586), Nagyszebenben (XVII. század), Segesváron (1552., máskor 1823. van alapítási évként feltüntetve), illetve 1847-től Brassóban (Kiss, 1929).

Az állami szabályozás bevezetése előtt (de feltételezhetően utána is) a nemzetiségek lakta területeken természetes volt, hogy a tanítókat a nemzetiségek nyelvén képezték. Ezt látszik igazolni az országgyúlés sérelmi bizottságának 1807-ben írt kérése: „Gondoskodjék őfelsége [...] tanítóképző-intézetek felállításáról, melyekben a tanítójelöltek anyanyelvükön kívül a magyar nyelvből is oktatást nyerjenek" (Kiss, 1929. 100. o.). A magyar nyelvü képzés követelése nyilvánvalóan XIX. században az erősödő magyar nacionalizmussal függ össze. A nemzeti érzelmek erősödése azonban nem csak a magyarságra volt jellemző ebben a korban.

A XIX. század közepén autonomizálódó nemzeti, nemzetiségi törekvések az oktatás nyelvét is érintették, mint ahogy a XV-XVI. században a kisebb(ségi) nyelveken megjelent hiteles bibliafordítások jelentették a nyelvi és etnikai emancipációt. Így 1848-ban a nemzetiségi követelések között szerepelt egyebek mellett a nemzetiségek saját nyelvü oktatása is. Az 1868-as népoktatási törvény pedig de jure kimondta, hogy „Minden növendék anyanyelvén nyerje az oktatást, amenynyiben ez a nyelv a községben divatozó nyelvek egyike" (Báthory - Falus, 1997. 559. o.).

\section{Az első tanítóképző intézet Magyarországon}

A tanulmány írásához felhasznált, a magyarországi német tannyelvủ oktatást érintő szakirodalom a tekintetben egységesnek látszik, hogy a terület első német nyelvü tanítóképzőjét 1818-ban Pyrker János ${ }^{27}$ szepesi püspök saját székhelyén,

\footnotetext{
${ }^{26}$ Például az ortodox Románia más felekezetű nemzetei vagy a cseh és szlovák névadás vallási kapcsolatai (bővebben M. Pintér megj. alatt.).

${ }^{27}$ Pyrker fános László mint szepesi püspök akkori székhelyén, az északkelet-felvidéki Szepeskáptalanban 1819-ben már nyitott német tannyelvü tanítóképzőt (a szepesi szászságra tekintettel).
} 
Szepeskáptalanon (más néven Szepeshelyen, szlovákul Spišská Kapitula, németül Zipser Kapitel) alapította. Mivel az intézet alapításakor a nyelvhasználatot külön rendelet nem szabályozta (ez a későbbiekben megváltozott), valószínűsíthető, hogy Pyrker tulajdonképpen megalapította az első német nyelvű képzőt. A lakosság nyelvének megfelelő nyelven folyó tanítóképzés iránti elhivatottságát jelzi, hogy néhány évvel később 1828-ban Egerben (akkor már egri pátriárka érsekként), megalapította az első magyar tanítási nyelvű önálló tanítóképző intézetet is ${ }^{28}$ (Olejník, 2007).

A Pyrker által alapított szepességi tanítóképző megalapításának időpontját tekintve a magyar nyelvű szakirodalomnak nem sikerül egységes álláspontra jutnia. Például Nagy szerint (Nagy, 1979) Pyrker László egri érsek 1818-ban szervezett német tannyelvű tanítóképző intézetet Szepesváralján. Ugyanakkor más források egy évvel későbbre teszik az intézet alapítását: Molnár szerint Pyrker László szepesi püspök 1819-ben létesített önálló, német tanítási nyelvü tanítóképzőt (Molnár, 2007). Ugyanezt támasztja alá Kovács és Grundig de Vazques is, akik szerint Szepeskáptalanban 1819 őszén megnyílt az első önálló, más oktatási intézményekkel kapcsolatban nem álló német tannyelvü tanítóképző intézet (Kovács - Grundig de Vazques, 2011). A szlovák nyelvű források, de legfőképp a tanítóképző épületére kihelyezett emléktábla azonban egyértelműen eldöntik a vitát: az intézetet 1819 őszén nyitották meg, és akkor is indult el az oktatás.

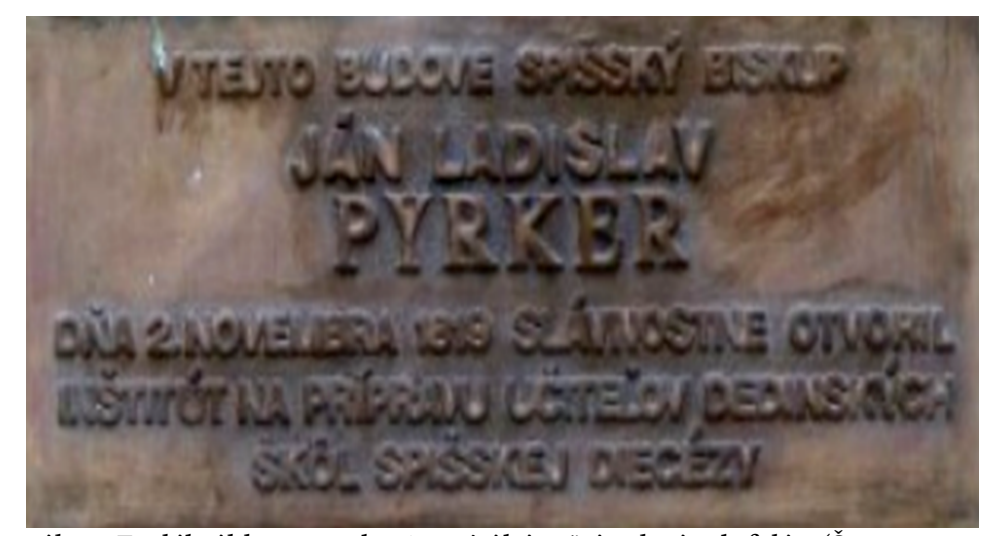

1. ábra: Emléktábla az egykori tanítóképző épületének falán (Šotter, 2012)

http://www.kislexikon.hu/pyrker_janos_laszlo.html Letöltés ideje: 2019. 09. 15. A Fejér megyei Lángon (ma Soponya) német családból született ciszterci szerzetes 1818-ban lett szepességi püspök, és - egyebek mellett saját jövedelméből - tanítóképzőt hozott létre. https://mno.hu/migr_1834/pyrker-janos-egriersek-a-mecenas-450327 Letöltés ideje: 2019. 09. 15.

${ }^{28} \mathrm{http}: / /$ lexikon.katolikus.hu/K/katolikus\%20tanító-\%20és\%20tanítónőképző\%20intézetek.html Letöltés ideje: 2019. 09. 15. 
Az áttekintett szakirodalom és dokumentumok alapján egyértelműen kijelenthető, hogy az intézetben 1819 novemberében kezdődött el az oktatás és kisebb megszakításokkal 1949-ig tartott (az utolsó tanév az 1948/1949-es volt), amikor az állam 1949. augusztus 31-én különféle incidensek után (például betörés a tanári szobákba, érettségik szabotálása) betiltotta a tanítóképző intézet működését. A megszűnő tanítóképző diákjai a közeli Lőcsén tanultak tovább, az oktatóknak azonban az állam nem kínált fel másik állást (vö. Olejník, 2007). A tanítóképző épületét a katonaság, majd pedig a rendőrség foglalta le és használta. Tanítási célokra csak 1990 után kezdték el újra használni, fán Vojtaššák püspök papi szemináriuma számára. Az épület jelenleg a szepességi püspökség birtokában van, ahol - egyebek mellett - teológiaoktatás is folyik.

\section{Az oktatás nyelve az elsó német nyelvŭ tanítóképzöben}

Neszt (2014) szerint az első középfokú, szakiskolai jelleggel bíró, önálló tanítóképző Szepesváralján nyílt meg 1819-ben, melynek tanítási nyelve a német és a szlovák volt. Az intézmény nyelvének pontos megállapítása a rendelkezésre álló forrásanyagok alapján nem egyértelmű, mivel mást állítanak a magyar és mást a szlovák nyelvű források. Az 1819-1851 közötti időszakban a hivatalos nyelv a latin volt, bár a történelmi Magyarországon 1848-ig volt csak hivatalos. A kor szellemének megfelelően azonban a szlovák, a német és a latin is oktatási nyelv voltak - a forrásanyagok mellett ezt támasztja alá az intézmény szellemisége is, hiszen népi tanítókat neveltek, akik feladata a falusi emberek tanítása volt, az pedig csak úgy lehetett sikeres, ha azok vernakuláris nyelvén tanulnak.

A tanítóképző (Praeparandorum) többnyelvűségét mutatja első igazgatójának, furaj Pálešnek (1753-1833) munkássága is. Ténykedése során (1819-1824 között dolgozott a képzőben) 1820-ban megírta az első szlovák nyelvű pedagógiai tankönyvet és kántoroknak szóló oktató könyvecskét. Érdekesség, hogy 1828-ban, kevesebb, mint tíz év működés után Zábojský megírta az intézet első történelmi visszaemlékezését is.

$\mathrm{Az}$ intézet indulása után mintegy három évtizeden keresztül viszonylagos nyelvi nyugalomban taníthattak, az első komolyabb nyelvi szabályozás 1852-ben történt, mikor Ladislav Zábojský szepességi püspök a szlovákot tette meg hivatalos tanítási nyelvnek, ugyanakkor a német diákoknak megengedve a német használatát. A következő nyelvi szabályozásra 1879-ben került sor, Császky György érsek a magyart tette az oktatás hivatalos nyelvévé. Emellett a szlovák választható 
tárgy maradt, illetve a tanítási gyakorlat továbbra is szlovákul folyt (bár a szlovák nyelv oktatását folyamatosan csökkenő óraszámban tartották). Az oktatás nyelve az első világháború után változott meg, 1919. október 15-én megkezdett tanévben már szlovák nyelven folytatták azt.

\section{Tárgyi feltételek és az oktatás rendje az első német nyelvú tanítóképzőben}

Kiss szerint (1929) Pyrker fános László szepesi püspök 1819-ben jelentős pénzadománnyal és a káptalanja, illetve lelkészkedő papsága támogatásával (2000 arany) alapította a tanítóképzőt. Az intézmény az ősi Árpád-kori székesegyház szomszédságában kapott épületet.

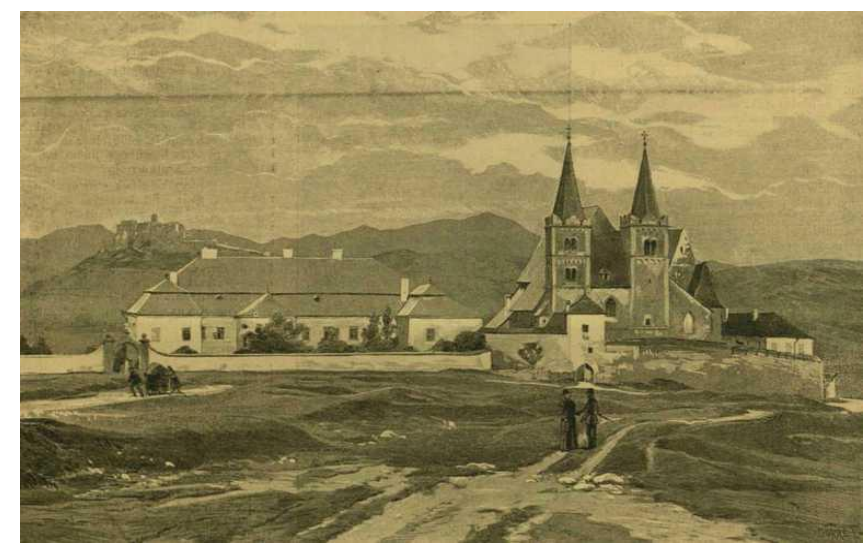

2. ábra: Szepeshelyi püspöki palota és székesegyház ${ }^{29}$

A tanév november elején kezdődött és augusztus végén zárult: két félévből állt, mindegyik végén vizsgával, az egyes tantárgyakat „kitűno”, „első rendü” és „másod rendü” osztályzatokkal értékelték (Mészáros, 1984).

A képzés indulásának kezdetére maga Pyrker is úgy emlékezik önéletírásában, hogy 1819. november elején indult. A püspöki szeminárium földszintjének egy használaton kívül álló termét egy fal felhúzásával két tágas szobára osztották: az egyikbe hat ágy került, ez lett a hálószoba, mivel kezdetben ennyi tanulója volt az intézetnek. A másik helyiség lett a tanulószoba, ide asztalok, székek és egy szekrény került a könyvek és kották számára (Pyrker, 1966). A bentlakásos alapon müködő intézet diákjai az intézet konyháján ebédeltek. Az intézet alapszabályban rögzítette, hogy a tanulással összefüggő összes költséget az intézmény állja, így lehetőséget biztosítva a szegényebb tanulóknak is. A kollégium és a menza az

\footnotetext{
${ }^{29} \mathrm{http}: / /$ keptar.oszk.hu/html/kepoldal/index.phtml ?id=60 329 Letöltés ideje: 2019. 09. 15.
} 
1847/48-as tanévben megszűnt, később egy ideig újra működött, mialatt a diákok létszáma is emelkedett.

\section{A képzés hossza és az oktatott tantárgyak}

A képzés hossza az indulástól számítva folyamatosan növekedett: 1819-1871 között a képzés 2 éves, 1871-1883 között 3 éves, 1883-1940 között pedig 4 éves volt. 1940-1945 közötti időszakban a képzés 5 évre nőtt, miközben a tanított tárgyak száma is növekedett. A második világháború után a képzés ismét 4 éves lett, míg a kommunista rezsim 1949-ben be nem záratta (Gunčaga - Lang, 2017).

A diákok kezdetben a katolikus egyház által jónak látott tárgyakat tanultak (keresztény vallás vagy katekizmus, módszertan, helyesírás és szépírás, aritmetika, bibliai történetek az Ó- és Újtestamentumból, ének, zene és liturgia; vö. Gunčaga, 2014), a világi tárgyak mint a történelem, nyelvek csak az 1890-es évektől erősödtek. Így az 1860-as évektől ${ }^{30}$ az elméleti tárgyak mellett a II. évfolyam növendékei hetenként egy napot töltöttek tanitással és megfigyeléssel a képző minta-iskolájában (Kiss, 1929). Az oktatás alapjai a tanítóképzőkben a népiskolai tankönyvek voltak. A növendékek a minisztérium által előírt tankönyvek anyagát és annak népiskolai feldolgozási módját tanulták meg (Kiss, 1929).

1864-1868-ig a tanítóképzők tanterve nagyjából egységes volt: hittan mindkét évfolyamban (összesen heti 4 óra), nevelés- és oktatástan (összesen heti 5 óra), olvasókönyv kezelése (összesen heti 4 óra), reáliák (természetrajz, földrajz) (összesen heti 4 óra), magyar-, tót- és német nyelvtanítás módszere (egyenként heti 4 , összesen 12 óra), számtan mindkét évfolyamban (összesen heti 4 óra), szépírás (heti 2 óra), rajz (heti 2 óra), gazdaságtan (heti 1 óra), orgonálás (heti 6 óra), éneklés (heti 2 óra) és tanítási gyakorlat (heti 4 óra). Összesen heti 50 óra (vö. Kiss, 1929. 109. o.).

1868-tól fokozatosan emelték a müvészeti képzés óráit (zenei kör létesítése), erősödött a kántori képzés, illetve bevezették a szlovák nyelvtan oktatását. A következő nagy tantervi változás 1905 -ben volt, amikor erősítették a vallási tárgyak oktatását: például a kántori hivatást erősítendő hangszeroktatást és éneket (1906tól a végzett hallgatók a tanítói mellett kántori oklevelet is kaptak), a 3. és 4. évfolyam hallgatói a vasárnapi misén kántori gyakorlatként orgonáltak. Később az önképző körök bevezetésével gyakorolták a vers- és prózamondást, tulajdonképpen

${ }^{30}$ Az 1860-as évek előtt tárgyakat lásd Márkus - M. Pintér, 2019. 98-99. o. 
a nyilvános fellépések előkészítéseként (Olejník, 2007). A folyamatos fejlődésnek, a tantervek folyamatos bővülésének az első világháború vetett véget.

Az 1883-1905 közötti tanévekben a tanított tárgyak és óraszámaik is módosultak: a már négy évfolyamos képzőben az alábbi tárgyakat tanították: hit- és erkölcstan, pedagógia, testnevelés és egészségtan, pszichológia, didaktika, pedagógia- és iskolatörténelem, iskolai gyakorlat, magyar nyelv és irodalom, német nyelv, szlovák nyelv, történelem, földrajz, matematika, természetrajz, fizika, gazdaságtan, ének-zene, rajz, szépírás, torna.

A XX. század eleji tantárgyak immáron több témakörben, tantárgycsoportban mozogtak, amelyeket az alábbiakban lehet meghatározni: vallás, nyelvek (anyanyelv, idegen nyelvek), pedagógia-didaktika (tanítás módszertana, pedagógiatörténet - elmélet és gyakorlat), ének-rajz-hangszerismeret (éneklés és elmélete, hangszeres gyakorlatok hegedűn, gitáron és orgonán), természettudományok (földrajz, természetrajz, matematika, fizika, kémia), gazdálkodáshoz szükséges tudások (mezőgazdaság, mértan, egészségtan).

Az 1919/1920-as tanévtől a képző koedukált intézménnyé vált - az oktatásba beengedték a lány diákokat is. A szabad szellem áramlásaként 1929-ben (az intézet 100 éves fennállásának ünnepléseként) a diákok még cserkészegyesület létrehozásán is munkálkodtak, amit végül egy másik intézményben hoztak létre.

Az 1940-től induló utolsó évek oktatása a tantárgyak tekintetében nem hozott sok újdonságot, viszont a tárgyak heti óraszámában tapasztalható az intézet korai korszakában még jelentős arányban jelen lévő vallási-erkölcsi tárgyaktól a gyakorlatias tárgyak felé történő elmozdulás (Olejník, 2007).

\section{Az intézet jelentösége}

Az intézet csaknem 130 éves fennállása alatt 1777 tanítót nevelt ki. Jelentősége nem csak a benne oktatott diákok miatt nagy, hanem mert a történelmi Magyarország első tanítóképző intézménye volt, illetve egyházi intézményként egy időre képes volt az államtól is függetlenedni. Népi tanítókat képzett (vö. Gunčaga, 2014), akik a népnemzeti tudás mellett egyházi oktatásban is részesültek - ezzel hirdetve és terjesztve nem csak a tudást, hanem a vallást is. Katolikus intézmény volt ugyan, de falai között nem csak katolikusok tanulhattak, hanem például evangélikus hitűek is. Az oktatott tárgyak fókusza időről időre változott, de az oktatás szellemisége mindvégig megmaradt: a cél olyan tanítók képzése volt, akik a legkisebb falvakban is képesek voltak a műveltség, a tudás és az erényes lét tanítására a közösség saját nyelvén. 


\section{Német tannyelvűség az 1848-49-es szabadságharc leverése után}

A tanítás nyelve a tanítóképzőkben azon a meggondoláson alapult, hogy a tanítójelöltek azon a nyelven tanuljanak, amelyen tanítani fognak. Azonban az 184849-es szabadságharc leverése után azonban emellett a magyar nyelv háttérbe szorításának szándéka is meghatározó volt. Az 1856. évi január 20-án kelt rendelet szerint a képzők tannyelve a következőképpen alakult (Kiss, 1929):

- a kalocsai, esztergomi, pécsi képzők tannyelve magyar és német

- a pesti képzőkben a német a tannyelv (egyes tárgyakat magyarul is lehetett tanítani)

- a nagyszombati, kassai és besztercebányai tanítóképzők tanítási nyelve német és tót

- a sopronié német és horvát

- Ungváron magyar-német-rutén

- Nagyváradon német-oláh (görög katolikus képző)

- Arad német-oláh (görög-keleti oláh képző)

- Versec, Zombor német-szerb

- a nagyváradi, szatmári és győri képzőkben a tannyelv magyar (a német egyenjogú a magyarral)

Vagyis - a fenti felsorolásból látható - a német nyelv az összes felekezeti képzőben a tannyelvek között szerepelt. „A tanítóképzők tanítási nyelvei között az önkényuralom céljainak megfelelően, a német nyelv került a vezető helyre. A színmagyar vidékek képzőjében a német és a magyar nyelv egyenrangú volt. Nemzetiségi területeken pedig a német nyelv mellett az illető nemzetiségi nyelv is helyet kapott. Így voltak német-tót, német-oláh, német-horvát, német-rutén-magyar, német-szerb nyelvű tanítóképzőink. A pesti képzőkben 1856-57-től pedig csupán német volt a tanítási nyelv egészen 1860-61-ig" (Szakál, 1934. 57. o.). A tanítványok közül a németül tudók mindenütt előnyben részesültek. 1856-ban katolikus minta-tanodát állítottak fel Pesten, ezzel állt kapcsolatban a tanítóképezde, ahol megszűnt tannyelv lenni a magyar, idegen nyelvű, magyart nem is értő egyén került az intézet élére, az előadási nyelv a német lett. Így volt ez a többi képzőben is, például a kassaiban 1860-ig három nyelven folyt a tanítás (Kiss, 1929). 1858 után az új tanítóképzőket lehetőleg nem magyar ajkú területekre telepítették, a többnyelvű vidékek elsőbbséget élveztek. A nemzetiségek lakta vidékeken előfordulhatott, hogy egyáltalán nem tanítottak magyarul, mivel a második nyelv kötelezően a német volt. 


\section{Az oktatás körülményei és folyamata néhány német nyelvü képzöben a szabadságharc után}

A pesti képző 1856-ig három teremből álló bérelt helyiségben müködött, 1856-tól a tanhelyiséget és a fütést a város adta. Ez a Háromkorona utca 16. számú házban volt, és csak két tanteremből állt, zeneterem nélkül. Az intézetnek volt „200 kötetet meghaladó csinos könyvtára; 1 orgonája, 2 fis-harmónikája, 3 szekrénye, 1 villanygépe, 1 légszivattyúja, 1 földtekéje” (Kiss, 1929. 113. o.). Az ungvári képző a vár kapubejáratánál levő két szobában volt, melyek helyett később a várudvaron emeltek két tantermet magába foglaló épületet. Az épületek, tantermek, felszerelések nem voltak megfelelőek, erről számos panaszt olvashatunk. Az evangélikus képzők közül legjobban a soproni volt megszervezve, melynek külön egyemeletes épületében három tanári lakás és 14 szobából álló internátus volt (Kiss, 1929. 115. o.).

Erdélyben német nyelvű volt a nagyszebeni tanító- és a segesvári tanítónőképző (Donáth, 2008), továbbá Medgyesen, Brassóban és Besztercén volt még német nyelvű képző. A felsőlövői képző 1845-ben alakult, Wimmer Gottlieb Ágoston alapította. A tanítás nyelve német volt. Eszményképe a szemináriumi kiképzés, a tanítókat három éven át iskolamester-inasokként mindenben ki kellett oktatni, ami az iskolamesterséghez és orgonistasághoz tartozott. A szemináriumba három elemi osztály és egy előkészítő osztály elvégzése után juthatott be a jelölt. A megkövetelt életkor 13-18 év volt (Kiss, 1929). Az egyes tárgyak módszerét „Schulmeisterkunde" néven tanították, ami testtant, lélektant, általános nevelés- és oktatástant jelentett (Kiss, 1929).

1854 októberében az angolkisasszonyok intézetét bízták meg egy tanítónőképző felállításával, mely végül 1856. november 5-én nyílt meg két évfolyammal, Pesten. Ez volt az első női képző Magyarországon. A tanítás nyelve itt is német volt, egészen 1868-ig (Neszt, 2014).

\section{A tanítás nyelvének kérdése a kiegyezés után}

A kiegyezés után a magyar tannyelv előtérbe kerülése jellemzi a tanítóképezdéket. Budapesten a római katolikus női képzőben (Angolkisasszonyok) 1868-ig német, 1868-tól magyar volt a tannyelv. Kassán a római katolikus női képzőben (Szent Orsolyarend) magyar-német volt a tannyelv, akárcsak Sopronban a római katolikus női képzőben (Szent Orsolyarend) (Neszt, 2014). 
Az 1880-as évek elején a kassai és soproni római katolikus női és a felsőlövői evangélikus férfiképzők a német mellett a magyar nyelvet párhuzamosan alkalmazták tanítási nyelvül. Tizenhárom képző volt nem magyar tannyelvú: a görög katolikus képzők közül a balázsfalvi, nagyváradi, szamosújvári és ungvári, a görögkeleti aradi, nagyszebeni és két ungvári képző, valamint az evangélikusok által fenntartott beszterczei, brassói, medgyesi, nagyszebeni és segesvári képzők (Neszt, 2014).

1884-ben a fennálló 70 intézet közül 55 volt kizárólag magyar tanítási nyelvü, magyar és német oktatási nyelvủ három, magyar és román oktatási nyelvủ kettő. Öt képzőben kizárólag német nyelven oktattak: a beszterczei, brassói, medgyesi, nagyszebeni és segesvári evangélikus tanítóképzőkben (Neszt, 2014). Ezek közül négyet az elkövetkezendő években megszüntettek.

1880 és 1900 között megszűnt a besztercei és a brassói német tannyelvű evangélikus tanítóképző, a segesvári evangélikus tanítóképző, valamint a medgyesi magyar-német tannyelvű evangélikus tanítóképző (1856-ben alapították). Megszűnt továbbá a nagyszombati római katolikus magyar-német-szlovák tannyelvü tanítóképző (1857-ben alapították) és a soproni magyar-német tannyelvű római katolikus tanítóképző (1865-ben alapították) (Neszt, 2014). Az erdélyi evangélikus egyház megszüntette a „paedagogisch-theologische Seminar”-okat, helyettük Nagyszebenben az 1868. évi törvény előírásának megfelelő önálló képző felállítását határozta el (Neszt, 2014).

1900-ban már csak nyolc tanítóképző nem volt magyar tannyelvú. A szamosújvári és nagyváradi görög katolikus férfi képzőben román volt a tanítás nyelve. A balázsfalvai görög katolikus és az aradi, nagyszebeni, és karánsebesi görögkeleti képzőkben román, a zombori görögkeleti képzőben szerb, a nagyszebeni evangélikus képzőben pedig német volt a tanítási nyelv (Neszt, 2014). 1905-ben Felsőlövőn, Nagyszebenben (evangélikus tanítóképzők) és Segesvárott (evangélikus tanítónőképző, ekkor már női képzőként) volt a tannyelv német (Neszt, 2014). 1919-től a temesvári római katolikus tanítónőképző válik német tannyelvűvé (Neszt, 2014).

„A háború előtt a férfiképzőkben közel egyharmad volt a nem magyar anyanyelvü diákok száma. Trianon után a nem magyar nyelvü diákok száma elenyészó, 1-3\% közötti volt, melyből a legnagyobb arányú a német, emellett található még szlovák és horvát.” „A női képzőkben szintén 1-3\% közötti volt a nem magyar anyanyelvủek aránya, itt is német és horvát anyanyelvü növendékek tanultak" (Neszt, 2014. 137. o.). Vagyis Trianon után a nem magyar tannyelvü tanítóképzés 
teljesen háttérbe szorult. Fontos kivétel az 1940/41. iskolai évtől működő evangélikus, német tanítási nyelvű koedukációs tanítóképző Szászrégenben. Az intézet alapításának célja a Magyarországon és Erdély északi részeiben lévő evangélikus német tannyelvű iskolák részére szükséges tanítók képzése (Neszt, 2014).

\section{A tannyelvet érintő törvényi szabályozás a kiegyezés után}

A kor szellemének megfelelő, magyarosításra törekvő, a nemzetiségek érdekeit sértő törvényt alkotott 1879-ben Trefort Ágoston: „Minden akár felekezeti, akár másnemű oly tanítóképző intézetekben, amelyekben a tanítás nyelve nem magyar - a magyar nyelv oly óraszámban tanítandó, hogy azt az egész tanfolyam alatt minden tanítójelölt beszédben és írásban elsajátíthassa...” - „tanítóul nem alkalmazható, aki a magyar nyelvet el nem sajátította..." (Rácz Fodor, 1993. 132-133. o.). Idegen nyelvű képesítésre 1948-ig volt lehetőség, majd 1958-tól újra lehetőség volt képesítőzni (Rácz Fodor, 1993) a kijelölt nemzetiségi képzőkben, németül a pécsi tanítóképzőben (Rácz Fodor, 1993).

„Az 1879-es törvény a tanítóképzés számára előírta, hogy a leendő tanítókat olyan alaposan kell kiképezni magyar nyelvből, hogy taníthassák azt, s kimondta, hogy az 1882 után végzettek közül sem tanítóul, sem segédtanítóul nem alkalmazható, aki a magyart ezen a szinten nem bírja. A vegyes lakosságú községekben csak magyarul tanítani tudó tanító alkalmazható. Az 1879-es törvény igen keményen érintette a felekezeti iskolafenntartást, hiszen a görögkeleti egyházak szerb, illetve román tannyelven, az evangélikus egyház pedig részben német tannyelven képzett tanítókat" (Nagy, 2005. 81. o.).

Az 1904/05. tanévben a 72.001/905.sz. körrendelet a magyar nyelv tanításáról rendelkezett a nem magyar nyelvú tanitóképző intézetekben. Az 1897. évi XVIII. tc. és a 17.284/1879 sz. utasítás végrehajtása igen változatos képet mutatott. A miniszteri jelentések problémaként említik, hogy az ezekben a képzőkben végzett, tanítóképesítő vizsgákon megjelenő tanulók közül többen nem tudtak olyan szinten magyarul, hogy képesek lettek volna magyarul tanítani, így megbuktak. A miniszter elrendelte, hogy az 1876. évi XXVIII. tc. 5.§ 3a pontjában számukra biztosított jogoknál fogva a királyi tanfelügyelők kérjék be minden iskolai év elején a tankerületükben lévő nem magyar nyelvű tanítóképző intézetek tanmenetét, órarendjét és a tankönyvek egy-egy példányát. Elrendelte továbbá, hogy a felvett növendékek esetében ellenőrizni kellett, hogy megfelelően beszélték-e a magyar nyelvet (Neszt, 2014). 
Mivel az 1879. évi törvény $2 \S$-a megkövetelte, hogy a jelölt képes legyen magyar nyelven tanítani, ezért minden jelölt köteles volt magyar nyelvből, egy, a tanfelügyelő által megadott magyar nyelvi tételből a képesítő bizottság előtt gyakorlati tanítást tartani - egy 1905-ös közoktatásügyi jelentés alapján. A hiányosságokat látva a VKM 72.001/905. sz. körrendelete elrendelte a nem magyar tannyelvű képzőintézetekben a magyar nyelv kötelező tanítását (Neszt, 2014).

\section{Statisztikai adatok a német nyelvű tanítóképzésről az Osztrák- Magyar Monarchia idejéből}

Mielőtt rátérünk az állami képzőkre és részletesebb bemutatásukra, áttekintünk néhány, a német nyelvű képzésre, illetve a német anyanyelvű diákokra vonatkozó statisztikai adatot. Ahogy az a 3. ábrán látszik, 1880/1881-ben a 68-ból német volt az oktatás nyelve 5 evangélikus, magyar-német 3 katolikus és 1 evangélikus preparandiának (Donáth, 2008. 16. o.).

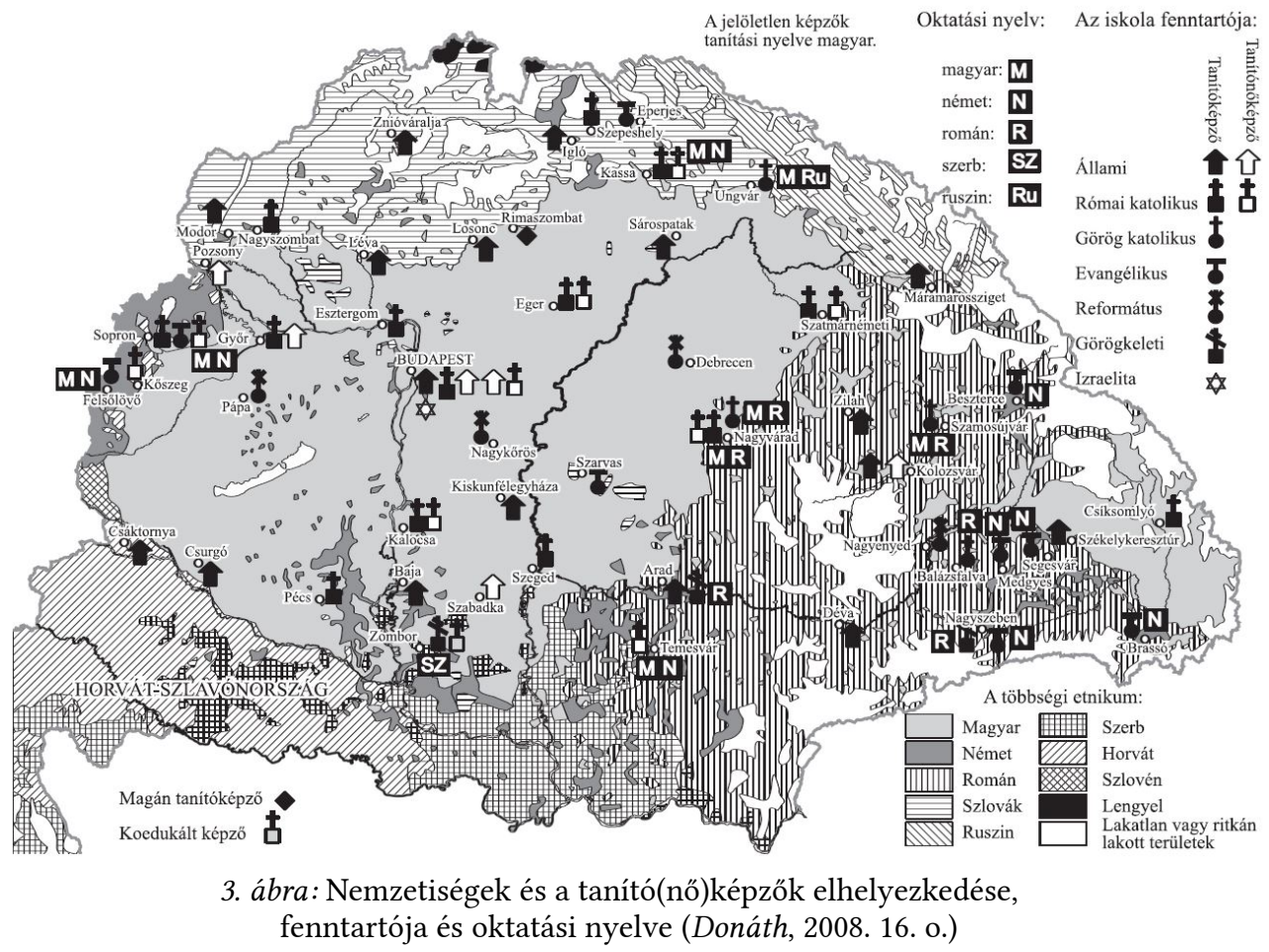

A diákok 11\%-ának anyanyelve a dévai és znióváraljai képzőben német volt, Aradon és Modoron a diákok megközelítőleg negyedének volt német az anya- 
nyelve, Temesváron és Iglón pedig a diákok majdnem fele volt német anyanyelvü (lásd 4. ábra).
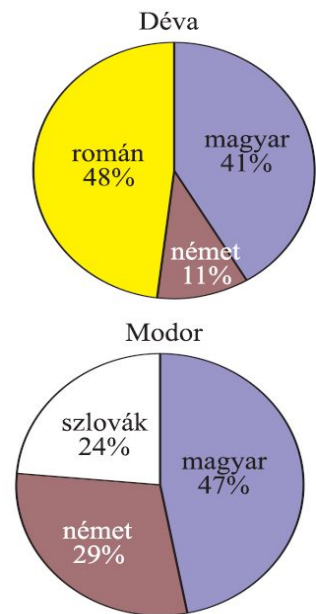

4. ábra: A növendékek anyanyelv szerinti megoszlása az állami tanítóképzőkben (Donáth, 2008. 18. o.)

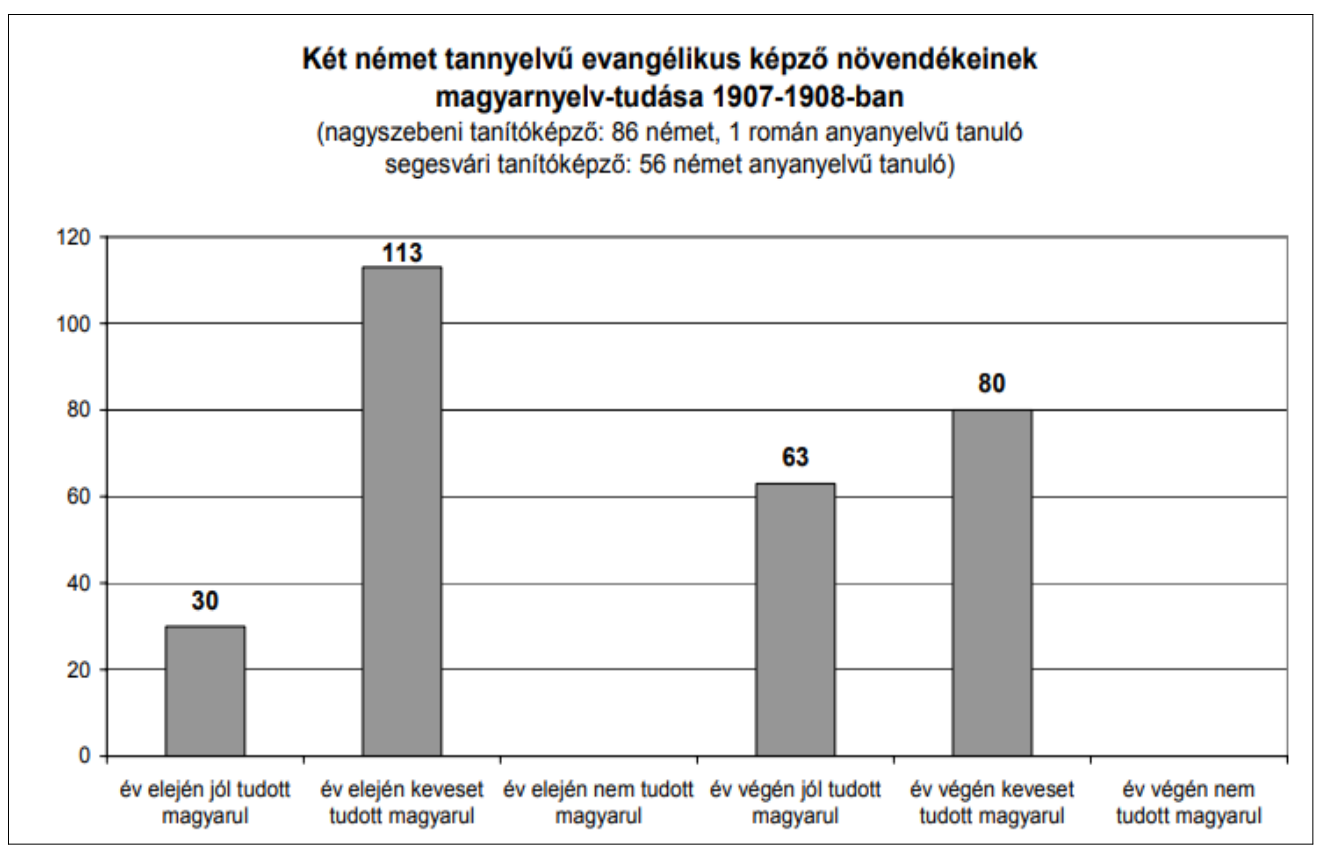

5. ábra: Német tannyelvű képzők diákjainak magyarnyelv-tudása (Donáth, 2008. 21. o.)

1907/08-ban (lásd 6. ábra) az ország 82 tanító(nő)képzőjéből 72-ben magyarul, két evangélikus intézetben németül folyt az oktatás (Donáth, 2008. 32. o.). 


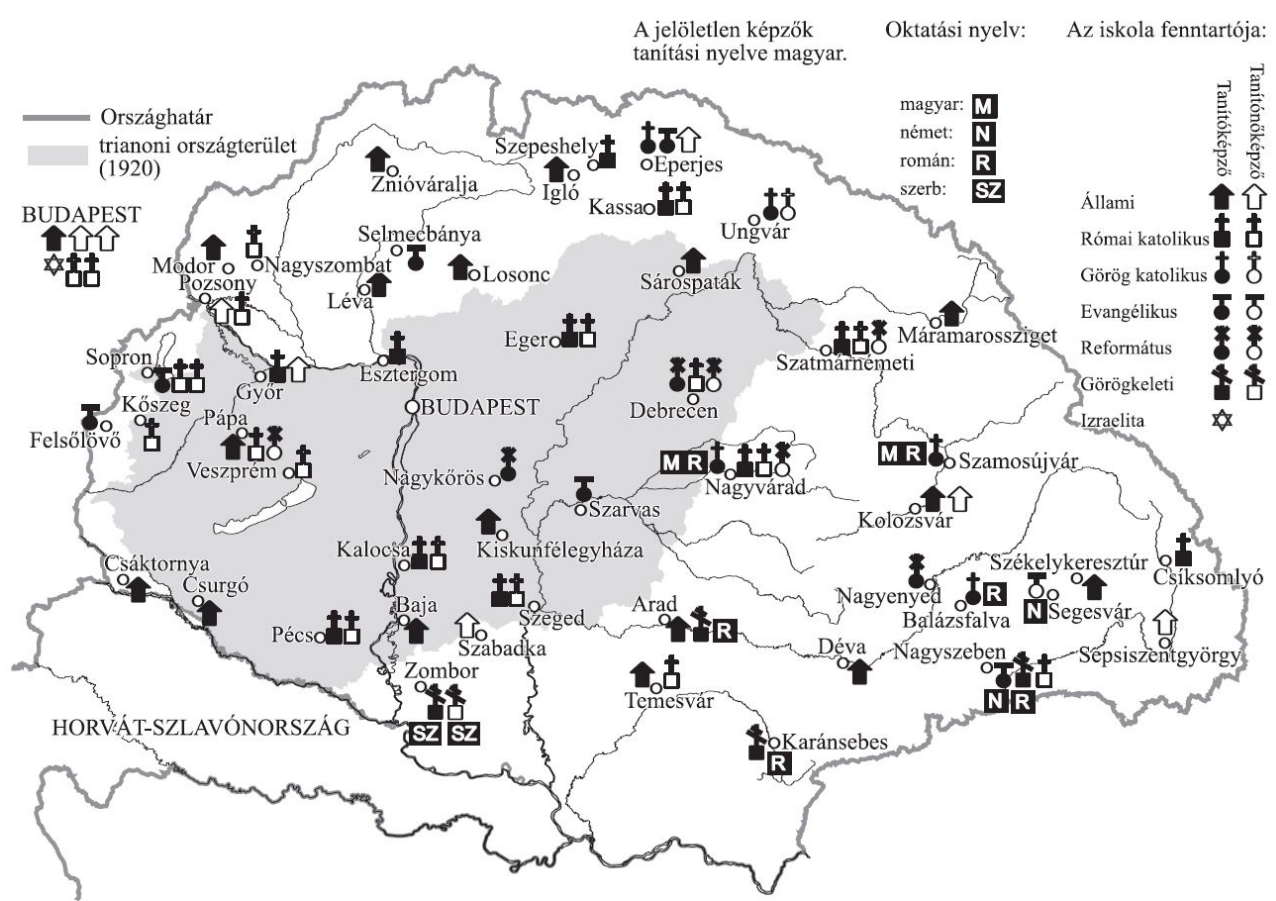

6. ábra: A magyarországi tanítóképzők és tanítónőképzők fenntartó és oktatási nyelv szerint 1907/1908-ban (Donáth, 2008. 32. o.)

1907-1908-ban a kiadott oklevelek közel 10 százalékát tették ki a magyar és valamely más tanítási nyelvü elemi iskolákban való tanításra jogosítók (vö. 7. áb$r a)$. Az ilyen jellegű bizonyítványok közel kétharmadát tanítóképzőkben állították ki, a kétnyelvű oklevelek több mint egyharmada állami képzőkből származott. A reformátusokon kívül valamennyi iskolafenntartó részt vállalt a kétnyelvű képzésben/képesítésben. A 152 kiadott oklevélből 72 a magyar mellett német nyelven való oktatásra is jogosított (Donáth, 2008. 53. o.). 


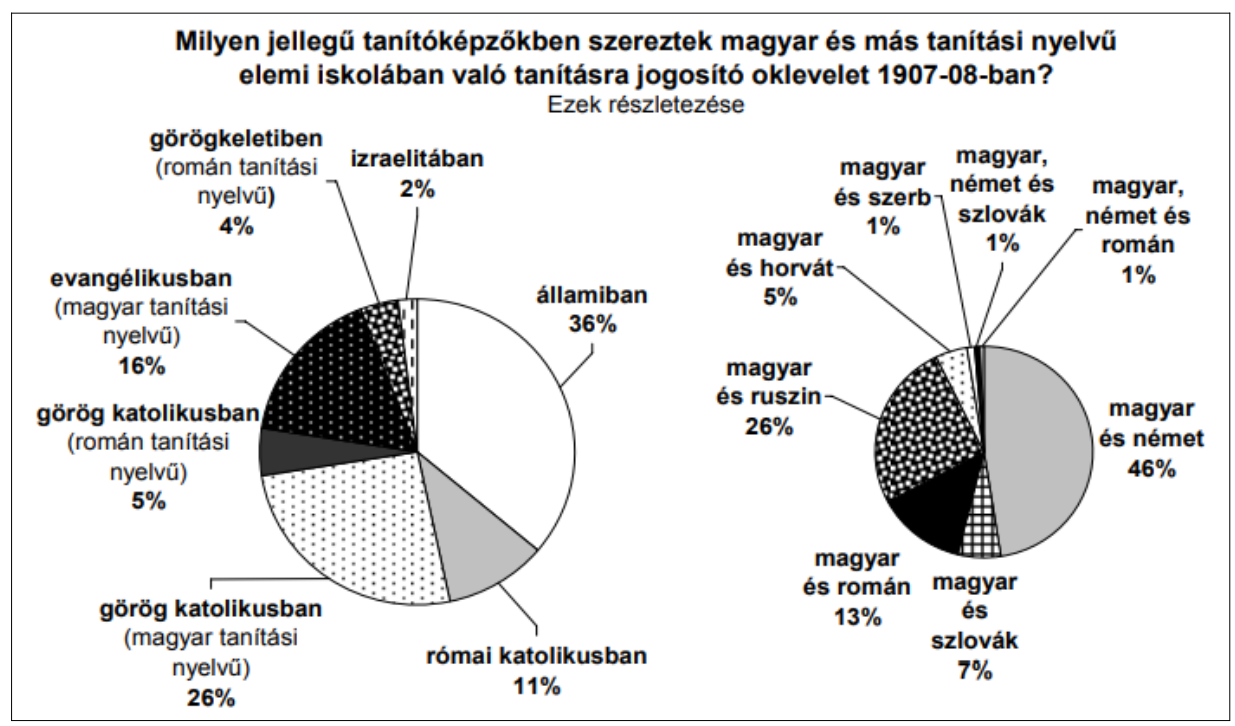

7. ábra: Magyar és más tanítási nyelvü tanításra jogosító oklevelek kiadása 1907/1908-ban a tanítóképzőkben (Donáth, 2008. 54. o.)

A tanítónőképzőkben sokkal magasabb a német nyelvű oktatásra is jogosító oklevelek aránya, mint a férfi tanítóképzőkben (lásd 8. ábra). Azt is látjuk, hogy az állami képzők mellett a római katolikus képzők aránya is magasabb, mint a férfi tanítóképzőknél.

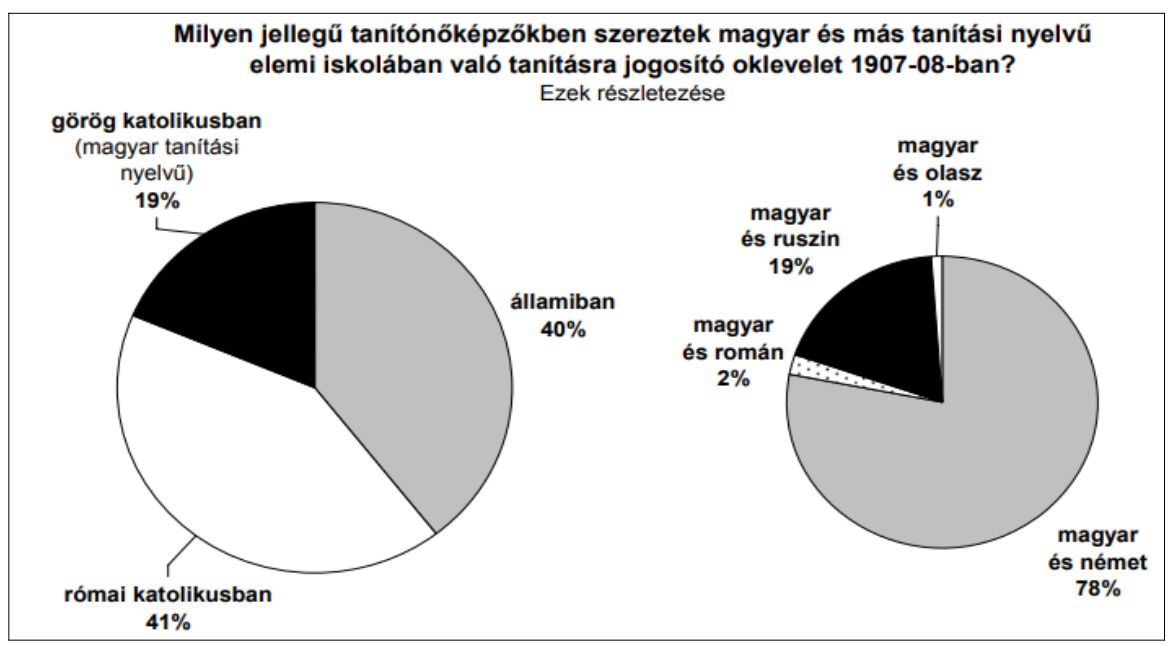

8. ábra: Magyar és más tanítási nyelvü tanításra jogosító oklevelek kiadása 1907/1908-ban a tanítónőképzőkben (Donáth, 2008. 54. o.) 
A tanítónőképzőkben kiadott kétnyelvű oklevelek között 71 német nyelven való tanításra jogosító akadt. A tanítóképzőktől eltérően a tanítónőképzők kétnyelvü okleveleinek kibocsátásában a katolikus és állami intézmények közel azonos részt vállaltak. Az összes oklevél 8,7\%-át kitevő, kizárólag román, szerb és német nyelvú iskolákban való oktatásra jogositó tanitói okleveleket görögkeleti, görög katolikus és evangélikus tanító-, illetve görögkeleti, evangélikus és római katolikus tanítónőképzőkben állították ki (Donáth, 2008. 55. o.). Ezt szemléltetik a következő ábrák.

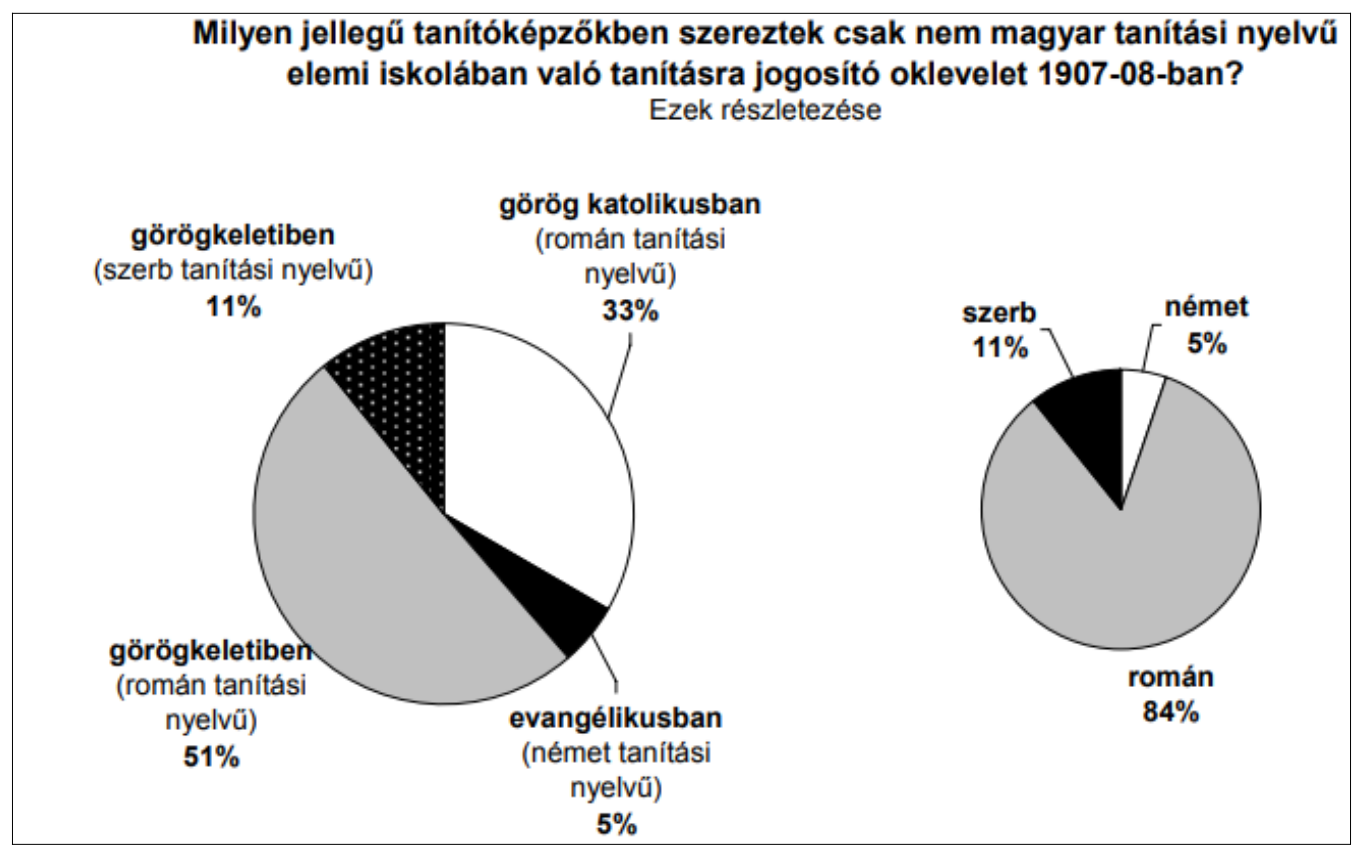

9. ábra: Csak nem magyar tanítási nyelvű tanításra jogosító oklevelek kiadása 1907/1908-ban a tanítóképzőkben (Donáth, 2008. 55. o.)

A tanítónőképzőkben - eltérően a férfi képzőktől - nem adtak ki csak román nyelvủ oktatásra jogosító oklevelet. Csupán szerb és német nyelvü tanításra jogosító okleveleket adtak ki (szerb nyelvüt a görögkeleti felekezet, német nyelvüt pedig a római katolikus és evangélikus tanítóképzők), a német nyelvű oklevelek nagyjából a harmadát (38\%-át) tették ki az összes ilyen jellegű oklevélnek.

Az 1917/1918. tanévben hasonlóan a 10 évvel korábbi állapothoz, az erdélyi szász területeken, Nagyszebenben és Segesváron tanitottak németül (Donáth, 2008). 


\section{A német tannyelvű állami képzők 1872 után}

A XIX. sz. vége felé az állami képzők tanítási nyelvét egy, 1872-ben kiadott miniszteri rendelet szabályozta, amelyek kötelezővé tette a magyar nyelvet a dévai és a modori képzők kivételével (Rácz Fodor, 1993). A német nyelv tanításának ügye csak részben nemzetiségi kérdés, hiszen a német majdnem 100 éven át kötelező tárgy volt, melyet minden évfolyamon legalább heti 2 órában volt kötelező tanulni. A második világháborúig német nyelvü iskolákra is lehetett (külön vizsgaként) képesítést szerezni (Rácz Fodor, 1993). 1941/1942. tanévben a budai férfi tanítóképző mellett Szászrégenben és Újverbászon, a koedukált képzőkben lehetett német tanítói képesítést kapniés evangélikus tanítóképzők): a né (vö. 10. ábra).

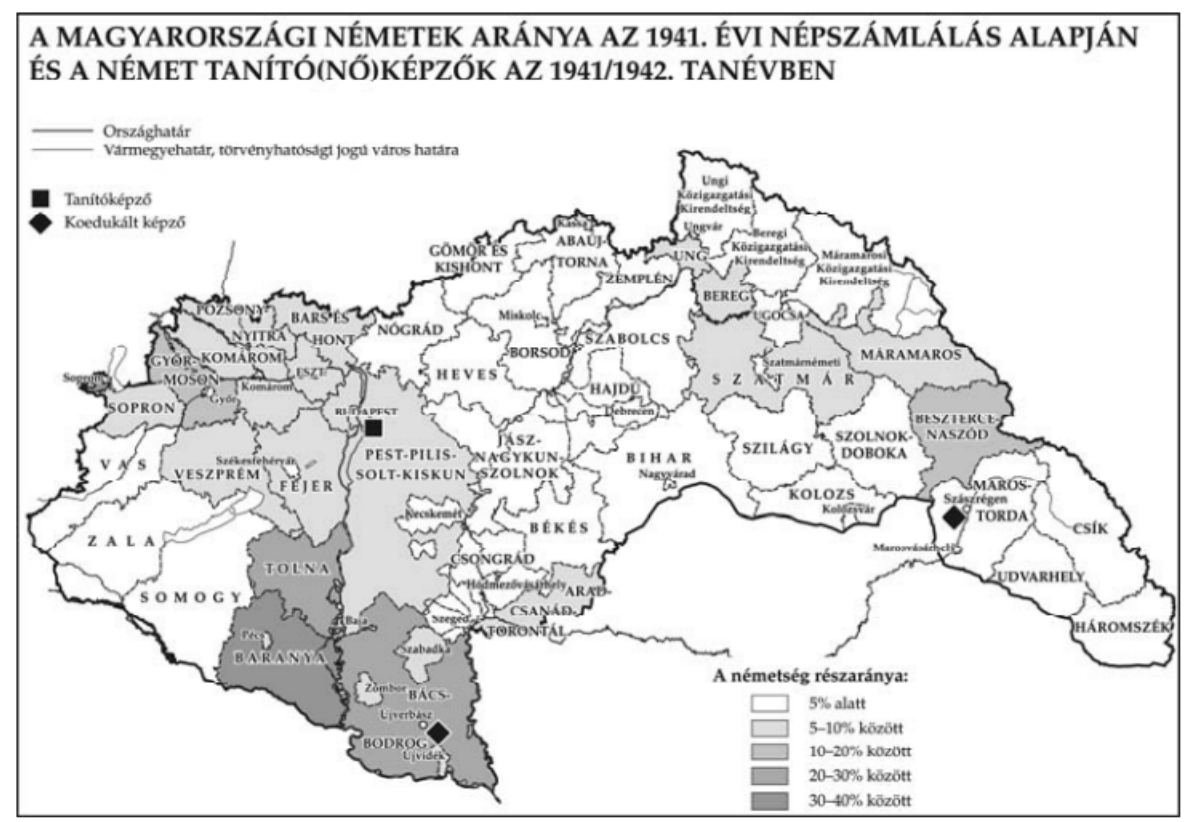

10. ábra: A magyarországi németek aránya és a német tanító(nő)képzők az 1941/1942. tanévben (Donáth, 2008. 117. o.)

\section{A Magyar Királyi Állami Németnyelvű Tanítóképző-Líceum}

A német nemzetiségi tanitóképzés ügye 1920-ban elöremozdult, napvilágot látott a vallás- és közoktatási miniszternek és a nemzeti kisebbségek miniszterének 48.696/1920. VKM sz. közös rendelete, mely szerint: „Annak biztosítására, hogy Magyarország német ajkú lakossága népiskolái számára oly tanítók álljanak rendelkezésre, akik a magyar és a német nyelvet egyaránt bírják [...] magyar és né- 
met tanításnyelvű tanító- és tanítónőképző intézetek felállítását, ill. meglevő intézeteknek ily nyelvü tanfolyamokkal való kiegészítését" határozták el 1920 szeptemberétől Baján, Győrött, Felsőlövőn, Sopronban és Szegeden (Donáth, 2008. 106. o.).

A német nemzetiségű magyar állampolgárok százezreinek első színvonalas anyanyelvi s módszertani képzést nyújtó tanítóképző megnyitásáig mégis 1939 szeptemberéig kellett várni ${ }^{31}$ (Donáth, 2008). Az intézetek elsődleges célja a hazai német nemzetiség értékeinek továbbörökítése, a nemzetiségi kultúrát továbbadó, színvonalas oktatásban részesülő tanítók képzése volt. Az Európában ekkor már előtérben lévő nácizmus áramlatai elkerülték a képzőket. A képzők a magyarországi németekért voltak - nem kapcsolódtak a nácizmushoz.

A Magyar Királyi Állami Németnyelvü Tanitóképző Líceum a budai állami tanítóképző ${ }^{32}$ akkori, Fery Oszkár utca 40. számú épületében (ma Kiss János altábornagy utca) 1939-től nemzetiségi tanítóképzőként működött (vö. Donáth,1998). 1939. augusztus 29-én Lux Gyula címzetes igazgatót kérték fel, hogy szervezze meg az ország történetében első, Magyar Királyi Állami Németnyelvü Tanítóképző-Líceumot Budapesten (Donáth, 1998). A kormányzat eredetileg azonos eljárásra törekedett a budapesti állami német nyelvủ tanítóképző és a szekszárdi „állami német tanításnyelvű gimnázium” szervezése során. Mindkettőt a kijelölt magyar tannyelvű intézményben, annak tanári karára, infrastruktúrájára támaszkodva, az óratervet alig módosítva kívánták létrehozni oly módon, hogy a magyar és a testnevelés kivételével minden tárgyat németül tanítsanak, közös igazgatás mellett. Az ugyancsak német származású, ám asszimiláns álláspontot képviselő Padányi-Frank Antal kategorikusan elzárkózott a német tanítóképző igazgatásától, s a két intézmény „ideiglenes” közös elhelyezésébe, s így a közös internátus irányításának vállalásába is csak a legkomolyabb nyomásnak engedve egyezett bele. Így Lux Gyula személyében megbízott igazgató került a budapesti német nyelvű tanítóképző élére (Donáth, 1998). A növendékeket újsághirdetések

\footnotetext{
${ }^{31}$ 1933. május 9-én Bleyer Jakab deklarációt olvasott fel a Képviselőházban. Ebben az 1923-as kormányrendeletnek a középiskolákra s a pedagógus-utánpótlás biztosítására vonatkozó ígéreteit felidézve leszögezte: „sajnos az a tényleges helyzet, hogy [...] nincs egyetlen tanítóképző sem, ahol a német kisebbségi iskolák számára a német nyelv szempontjából csak távolról is megfelelő tanítók képeztetnének ki” (Donáth, 2008. 110. o.).

${ }^{32} \mathrm{Az}$ 1869-ben Krisztinavárosban megnyílt budai állami képző tantárgyai között már ott találjuk a német nyelvet. Heti három, illetve két órában tanulták a diákok kötelező tárgyként (Panyik, 1991. 14-15. o.). Az 1911-ben a jelenlegi Kiss János altábornagy utcai épületbe költözött budai tanítóképző tantervében a német nyelv heti két órával a képzés teljes ideje alatt jelen volt (Panyik, 1991. 40. o.). Az 1923-ban 5 évessé vált tanítóképzés óraterve 150 órát tartalmazott, ebből 10 óra volt a német nyelv, heti két órával a képzés teljes ideje alatt jelen volt (Panyik, 1991. 47-48. o.).
} 
útján toborozták. A 28 (23?) [beszúrás az eredeti szövegben - MÉ] jelentkezőből a túlkorosak és a németül gyengén beszélők kiszürése után 18 tanuló iratkozott be, ám rövidesen csak 15-en maradtak (13 katolikus és 2 evangélikus vallású). Valamennyien internátusi elhelyezést kaptak (Donáth, 1998). Német nyelvủ hazai tankönyvek hiányában átmenetileg a mennyiségtant, a természetrajzot, a csillagászati és fizikai földrajzot osztrák, illetve német tankönyvekből tanították, ám a történelem és a német nyelv tanításához sürgősen saját tankönyveket kívántak írni (Lux Gyula) (Donáth, 1998).

\section{Az oktatás körülményei}

Saját intézmény hiányában egy igazgatói szobában, két - dolgozószobául is szolgáló - tanteremben, külön zenetermeket és szertárakat nélkülözve, délutánonként komoly fútési gondokkal, hiányos felszereléssel, késve nyomtatásra került vagy a birodalomból későn érkezett tankönyvekkel dolgoztak. Különösen a gyakorlóiskola hiánya okozott problémát, hiszen a tanulók Budaörsre jártak hospitálni. A kedvezőtlen körülmények fokozott erőfeszítést igényeltek tanártól, diáktól egyaránt (Donáth, 1998).

A szakirodalmi feljegyzések szerint az 1942-1943-as tanévben a tanévzáró értekezleten Lux Gyula ismét súlyos gondokról szólt: „Mély fájdalommal és sebzett lélekkel kell megállapítania, hogy intézetünk most már negyedik éve saját épület nélkül és igen hiányos felszereléssel kénytelen működni; [...] egyelőre még kilátásunk sincs arra, hogy ez az állapot javuljon. Sőt... a helyzet még sokkal roszszabb [sic!] lesz, mert a jövő tanévben már öt osztállyal leszünk kénytelenek a magyar tanítóképző helyiségeit igénybe venni. Intézetünk valamennyi növendékének internátusban kell laknia, s így [...] kiszorítják a magyar tanítóképző növendékeit [...] A magyar tanítóképző intézet növendékeinek jelentékeny része így nem részesülhet internátusi ellátásban és nevelésben [...] ennek következtében a magyar közönség lelkében ellenszenv támad intézetünk iránt [...] Intézetünk eljutott fejlődésének abba a stádiumába, amikor már a gyakorlati képzésről is gondoskodni kell. [...] Gyakorlóiskolánk azonban nincs. Ebben a tanévben úgy tudtuk a gyakorlati kiképzést megoldani, hogy a pesthidegkúti állami népiskola tanulói bejöttek azokon a napokon, amelyeken gyakorlati tanítás volt [...] A szülők rossz időjárás esetén nem voltak hajlandók gyermekeiket ilyen hosszú útra elengedni, mert az autóbusz gyakran nem járt, s így a tanulók kénytelenek voltak gyalog bejönni vagy hazamenni. A mi tanulóink pedig Pesthidegkútra jártak hospitálni, ahol azonban mintaszerủ tanítást természetesen nem láthattak, s szintén ki voltak 
téve annak a veszélynek, hogy rossz időjárás esetén gyalog kellett menniök. [...] Súlyos gondként jelentkezik a tankönyvkérdés is. A tantárgyak egész sorából nem áll tankönyv a rendelkezésünkre. A miniszteri utasításnak megfelelően gondoskodott tankönyvek íratásáról és fordításáról, azonban különböző okoknál fogva a már megírt, ill. lefordított könyvek egy része mégsem jelenhetett meg. Az engedélyezett külföldi tankönyvek egy része viszont nem kapható, úgyhogy tanulóink kénytelenek jegyzetekből tanulni, ami azonban nincs megengedve. Két tárgyból, a honvédelmi ismeretekből és a gazdaságtanból, miután németül tanítani tudó tanárunk nincs, magyar tankönyvet használunk. [...] tanulóink jelentékeny része a »Német Ifjuság « c. szervezet tagja, ahol az intézeti neveléstől lényegesen eltérő, német nemzetiszocialista hatások alatt állanak, ami súlyos gondként hat." (Donáth, 1998. 131-133. o.).

Az 1943-1944. tanévben a német nyelvű képző megindította újabb, ötödik osztályát, amelybe 15 elsőéves kérte felvételét (egy gimnazista kivételével különböző polgári iskolákból), s Szászrégenből további két, Újverbászról és Bécsújhelyről egy-egy tanuló kérte átvételét. Ily módon a német képzőben a hallgatói létszám 73-ra nőtt. Az eredetileg „60 növendékre készült s legfeljebb 80 férőhelyű internátusban, (3 helyiség, 5 dolgozószoba, 4 felügyelő szoba, 1 ebédlő, 1 mosdóhelyiség 30 mosdókagylóval, 8 db WC és 1 betegszoba, 1 orvosi szoba) - ahol egy decemberi tisztiorvosi vizsgálat tanúsága szerint - ez idő szerint 142 növendék van elhelyezve, és így az elkerülhetetlen zsúfoltság miatt nemcsak a növendékek egészségi állapota veszélyeztetett, hanem a fertőző betegségek elterjedése sem akadályozható meg" (Donáth, 1998. 143. o.).

Az IV-V. évesek hospitálása ügyében megállapodtak a budakeszi német tannyelvü népiskolával, hogy a gyakorlati tanítások érdekében alkalmanként 12 tanuló jön be tanítónőjük vezetésével a Fery Oszkár utcai épületbe - a júniusban áthidalhatatlannak ítélt problémák lassan megoldódni látszottak (Donáth, 1998).

1944. április 3-án rendkívüli évvégi osztályozó értekezletre került sor. A XII. kerületi Fery Oszkár utcai tanítóképző-intézet épületét 1944. május 15-én hadikórház (Kriegslazarett 2/605.) céljaira kellett átadniuk (Donáth, 1998). De jure az egész 1944-1945. tanév során létezett az állami német nyelvü tanítóképző, már amenynyire a háborús, illetve frontviszonyok között erről egyáltalán szó lehetett (Donáth, 1998). 


\section{A nemzetiségi oktatás a második világháború utáni években}

1945 után törvények és törvényerejü rendeletek biztosították a nemzetiségek oktatási jogait, a következőkben ezeket mutatjuk be. 1946-ban a nemzeti kormány 330/1946. számú rendelete a nemzetiséghez tartozó tanulók nemzetiségi oktatása tárgyában úgy rendelkezett, hogy a nemzetiséghez tartozó tanulókat anyanyelven folyó oktatásban kell részesíteni. Az anyanyelvi oktatást állami iskolák létesítésével és fenntartásával, illetőleg államsegély nyújtásával kell biztosítani (1. §) (Föglein, 2006). Az 1949. évi XX. törvény, a Magyar Népköztársaság alkotmánya is biztosította a Magyar Népköztársaság a területén élő minden nemzetiség számára biztosítja az anyanyelvén való oktatásnak és nemzeti kultúrája ápolásának lehetőségét (49. §).

Az 1951/1952. tanévtől kezdődően indult csak meg a német nemzetiségi iskolahálózat fokozatos kiépítése. A második világháborút követően addig csak szlovák, délszláv (horvát, szerb, szlovén), valamint román nemzetiségi tannyelvű és nyelvoktató iskolák müködtek hazánkban (Föglein, 2006).

1952-ben megjelent a közoktatásügyi miniszter 859-417/1952. számú utasítása a nemzetiségi tanerők továbbképzéséről. Ez kimondta, hogy az általános iskolai tanítók nemzetiségi nyelv és irodalom szakon szaktanitói képesitést szerezhetnek. A képesítő- és az alapvizsga szóbeli és írásbeli részből állt. Német nyelv és irodalomból is lehetőség volt nyári szakosító tanfolyam elvégzésére. A tanfolyamra felvételüket kérhették a 45 évnél nem idősebb, rendes tanítói minőségben működő, politikai és szakmai szempontból fejlődőképes nevelők, akik nemzetiségi tanítási nyelvủ iskolákban vagy nemzetiségi nyelvet oktató magyar tanítási nyelvü iskolákban nemzetiségi nyelvet tanítanak, vagy akik nemzetiségi nyelvet nem tanítanak, de délszláv, román, szlovák, német nyelvismerettel rendelkeznek és a nemzetiségi nyelvek valamelyikének tanítására hajlandóságot éreznek (Föglein, 2006). A nyári szaktanítói tanfolyam Budapesten bentlakásos tanfolyamként került megszervezésre. A bentlakás valamennyi résztvevőre kötelező volt. A résztvevők elszállásolásának és élelmezésének költségeiről a minisztérium gondoskodott.

1957-ben megjelent a müvelödésügyi miniszter 859-8/1957. számú utasítása Milyen új feladatokat jelent a német nemzetiségi nyelvoktató iskolák részére a német nyelvnek, mint tanitható idegen nyelvnek bevezetése? címmel (Föglein, 2006). Ebben olvashatunk arról, hogy voltak olyan általános iskolák, amelyekben vegyes magyar és német (esetleg német és más nemzetiségű) tanulók tanultak együtt: „Baranya megye több iskolájában (Somberek, Mágocs, Gyód, Hímesháza, Boly, Beze- 
dek, Mária-kéménd, Palotabozsok, Vókány, Mecseknádasd, Kaposszekcső, Villány, Magyarboly) összevonták a német anyanyelvü oktatást, a német mint idegen nyelv oktatásával." (1957. március 21. a művelődésügyi miniszter 859-8/1957. mm számú utasítása) Az utasítás a német nemzetiségű tanulók szempontjából helytelennek és hátrányosnak tartotta ezt a gyakorlatot.

Az MSZMP nemzetiségpolitikai határozata 1958-ban külön foglalkozott a német nemzetiségi iskolákkal. Erre az esztendőre épült ki Magyarországon az 1951/1952. tanévben indított német nemzetiségi oktatás. Az 1958/1959. tanévben 8 német óvoda, 4 német nemzetiségi tannyelvủ általános iskola, 123 német nemzetiségi nyelvoktató általános iskola, 5 középiskola és 1 főiskolai tanszék működött Magyarországon (Föglein, 2006).

1960-ban megváltoztatták a nemzetiségi tannyelvủ iskolák státusát. Mủvelődésügyi minisztériumi körlevél írta elő, hogy az 1960/1961. tanévtől kezdve fokozatosan magyar nyelven kell tanítani a természettudományos tárgyakat és a testnevelést. A Művelődésügyi Minisztérium 44 167/1960. számú, valamint 44 159/1960. számú utasítása értelmében a nemzetiségi tannyelvű iskolákban eddig minden tantárgyat (a magyar nyelv és irodalom kivételével) nemzetiségi nyelven tanultak, ettől kezdve viszont a reáliákat és a testnevelést magyar nyelven oktatták. Az 1960/1961. tanévben Szarvason és Sopronban folyt nemzetiségi óvónő-, Budapesten pedig nemzetiségi tanítóképzés (Föglein, 2006).

1962-ben a Magyar Népköztársaság Elnöki Tanácsának 1962. évi 13. sz. törvényerejü rendelete a tankötelezettségről elöírta, hogy a nemzetiséghez tartozó tanköteles gyermekek számára - azokban a községekben (városokban), ahol legalább 15 ugyanazon nemzetiséghez tartozó tanköteles gondviselője kívánja - biztosítani kell, hogy a) anyanyelvükön részesüljenek oktatásban, vagy b) anyanyelvüket az iskolában kötelező tantárgyként tanulják.

1975-ben az oktatási miniszter 122/1975. sz. utasítása alapján a nemzetiségi oktatás összehangolt irányításának elősegítése érdekében véleményező és javaslattevő tanácsadó testületként Nemzetiségi Tanácsadó Bizottság jött létre (Föglein, 2006).

Az 1985. évi I. törvény az oktatásról kimondta, hogy a nemzetiségekhez tartozó gyermekek, tanulók anyanyelvükön, illetőleg két nyelven - anyanyelven és magyarul - részesülhetnek óvodai nevelésben és oktatásban, és az állam a feltételekről szervezetten gondoskodik (Föglein, 2006). Tehát újra lehetővé vált a nemzetiségi tannyelvú oktatás, amit 1960-ban megszüntettek. 


\section{Német nemzetiségi képzéssel foglalkozó tanítóképzök 1945 után}

A fentiekben leírt, törvényileg biztosított nemzetiségi oktatáshoz az államnak továbbra is biztosítani kellett a pedagógusokat, a pedagógusképzést. A következőkben a német nemzetiségi képzőhelyeket ismertetjük. Az 1950-es években léteztek ugyan nemzetiségi tannyelvü középfokú tanitóképzó intézetek (Drahos-Kovács, 1991), ám a Magyar Dolgozók Pártja 1956-os nemzetiségpolitikai határozatában megállapítja, hogy „Súlyos lemaradás mutatkozik [...] a német iskolahálózat fejlesztésében. Nincs német gimnázium, tanitóképző, nem folyik németnyelvü tanárképzés. Kevés a németnyelvủ általános iskolák és óvodák száma” ( $A z M D P$ nemzetiségpolitikai határozata az oktatásról - 1956).

A 859-P1. sz., 1956. február 22-én kiadott OM utasítás szerint az 1956/57. tanévben a pécsi Teleki Blanka Tanitóképzőben már német I. osztály müködött. A nemzetiségi tanítóképzői végzettség ugyanazokra az egyetemekre és főiskolákra való felvételre jogosított, mint más tanítóképzőké (Föglein, 2006). Később, 1976tól, a német kisebbség tanítóit Baján képezték a tanítóképző főiskolán. Csak a nemzetiségi szaktárgyakat tanulták anyanyelvükön, az összes többi tárgyat magyar nyelven (Nagy, 1979; Drahos - Kovács, 1991). ${ }^{33}$

1959-ben a müvelódésügyi miniszter 44 145/1959. számú utasításában a nemzetiségi oktatási és nevelési intézmények iskoláztatási és felvételi munkájáról felsorolják a nemzetiségi tannyelvü diákotthonos intézményeket. A német oktatási intézetek között találjuk a Felsőfokú Tanítóképző Intézetet (nemzetiségi tagozat), címe: Budapest, XII., Kiss János altábornagy u. 40. (Föglein, 2006).

A német nemzetiségi tanitóképzés folytatását Budán a Művelödési és Közoktatási Miniszter 39 473/1990. rendelete tette lehetővé: „A művelődési miniszter 1990. szeptember 1-jei hatállyal az oktatásról szóló 1985. évi I. törvény végrehajtására kiadott 41/1985.(X. 5.) MT rendelet 8 §-a (1) bekezdésének f) pontjában foglalt jogkörében a Budapesti Tanítóképző Főiskolán 4 éves kétnyelvű (magyar-német nemzetiségi) általános iskolai tanító szakot indít." ${ }^{34}$

A képzésnek ez a formája 8 féléves lett, szemben a 3 éves magyar nyelvü tanítóképzéssel. A hallgatók írásbeli és szóbeli felvételi vizsgájuk eredménye alapján kerültek az intézménybe. A képzés magas óraszámmal indult, a hallgatóság a szak minden tantárgyát német nyelven hallgatta, tanulta, és tett vizsgákat, szigorlatot,

\footnotetext{
${ }^{33}$ A magyarországi nemzetiségek alsófokú oktatásának 1945 és 1985 közötti körülményeit Föglein (2006) tekinti át.

${ }^{34}$ Képesítési követelmények 158/1994. (XI. 17. Korm. rend.)
} 
záróvizsgát. A hallgatók féléves részképzésen vettek részt, az első időszakban az egész csoport Németországban, az Augsburgi Egyetemen (Universität Augsburg).

Ma az Eötvös Loránd Tudományegyetem Tanító- és Óvóképző Kara (ELTE TÓK, a Budapesti Tanítóképző Főiskola jogutódintézménye) Idegen Nyelvi és Irodalmi Tanszék oktatóinak feladatkörébe tartozik a nemzetiségi német tanító szakos hallgatók célnyelven történő képzése. A 2006-ban bevezetésre került Bologna-folyamat következtében a nemzetiségi tanítók képzése már szakirányú képzésként jelent meg (Márkus, 2006; Juhász, 2007). Az átállás jelentős óraszámcsökkenéssel járt (Márkus, 2007) ${ }^{35}$. Az ELTE TÓK-on a tanító szakos, német nemzetiségi szakirányos hallgatók számára 2019-től lehetőség van német nyelvterületen, Ausztriában, tanító MA-diploma megszerzésére, ott ugyanis a tanítóképzés mesterszintű. Ez nemcsak presztízs-, hanem nyelvi szempontból is nagy jelentőségű, mert a részt vevő hallgatók a képzés két féléve alatt minden tárgyat németül végeznek. A képzésben való részvételt egy intézmények közötti, rektorok által aláírt szerződés teszi lehetővé, melyhez Erasmus-ösztöndíjas támogatást nyújtanak.

1990-ben Esztergomban, egy évvel azt követően, hogy az intézmény felvette Vitéz János esztergomi érsek nevét, elindult a német nemzetiségi tanítóképzés. „A szakindításnak a kiváltó oka elsősorban a városhoz közel fekvő német nemzetiségi településeken mutatkozó igény volt. Egyre több településen és egyre több osztályban tanítottak német nemzetiségi nyelvet, illetve terveztek ilyen jellegü oktatást. Az alsó tagozatos német nemzetiségi nyelv színvonalas oktatásának biztosításához rövid időn belül nagyszámú német nemzetiségi tanítóra volt szükség, s ebben sietett segítségre az esztergomi főiskola” (Horváthné Farkas, 2012, 10. o.). A főiskola 1993-tól ismét a római katolikus egyház fenntartása alatt múködött, 1993 és 2007 között Vitéz János Római Katolikus Tanítóképző Főiskola néven, 2008. január 1-jén az intézmény integrálódott a Pázmány Péter Katolikus Egyetembe, és annak Vitéz János Karaként folytatta munkáját (Horváthné Farkas, 2012). A kar (német nemzetiségi) tanító- és óvodapedagógusi képzéseit 2013. július 1-jétől a Vitéz János Tanárképző Központba integráltan látja el.

2007-től a Pécsi Tudományegyetembe integrálódott Illyés Gyula Főiskolán indulhatott a német nemzetiségi tanító szakirány Szekszárdon. Jelenleg Magyarországon kilenc felsőfokú intézményben folyik német nemzetiségi pedagógusképzés, német nemzetiségi tanítókat hét intézményben képeznek: Baján, Budapesten,

${ }^{35}$ A budapesti (ELTE TÓK) képzési programról bővebben lásd: Márkus, 2009; Márkus, 2016; Márkus Radvai, 2017. 
Esztergomban, Szarvason, Szegeden, Szekszárdon és Vácott (bővebben 1. Juhász, 2018; Márkus, megj. alatt és Müller, megj. alatt).

\section{Összegzés}

Tanulmányunkban felvázoltuk a magyarországi nemzetiségeknek szóló német tannyelvủ tanítóképzés kezdeteitől eltelt időszak kulcsfontosságú mozzanatait: elsőként bemutatva a szepeskáptalani képzőt, majd folytatva a XIX. és XX. század német tannyelvű nemzetiségi képzőivel. A német tannyelvủ tanítóképzés indulásának középpontját Erdély és a Szepesség jelentette - hiszen itt éltek nagy számban németek Magyarországon -, illetve sokat köszönhet az evangélikus egyház iskolafenntartó tevékenységének. A XIX. század második feléig természetes volt, hogy a német nemzetiség falvaiban az oktatás anyanyelven folyik, tanítóikat is ezen a nyelven képezték. Ez változott meg alapvetően az 1879-es törvénnyel. Ezután a nemzetiségi anyanyelvű képzők száma rohamosan csökkent Magyarországon, míg a trianoni békeszerződést követően az országban nem maradt nem magyar tanítási nyelvü képző, a határokon kívül maradtak a nemzetiségi képzők és diákjaik (Neszt, 2014). A II. világháborút követő, a magyarországi német lakosságot érintő retorziók után az 1950-es évek közepéig kellett várni arra, hogy először Pécsett középfokon, majd Baján felsőfokon, később pedig az országban több helyen indulhasson a német nemzetiségi tanítóképzés.

Ez ugyanakkor már nem a régi, nemzetiségi anyanyelvi oktatást jelenti, hanem egy ahhoz képest nagyon kevés óra- és kreditszámú célnyelvi képzést, ami nagyon nehezen tudja kielégíteni azt az intézményekre háruló feladatot, hogy a nemzetiségi anyanyelvet és kultúrát közvetítsék az előrehaladott asszimiláció által érintett nemzetiségi közösségek felé. Érdekes tény annak fényében, hogy az első 'nemzetiségi' képzők egyházi fenntartásúak voltak, hogy a jelenlegi hét, nemzetiségi tanítókat képző egyetem/főiskola közül is három egyházi fenntartású felsőoktatási intézmény.

A nemzetiségi óvodapedagógus-képzés támogatására a Miniszterelnökség és a Bethlen Gábor Alapkezelő Zrt. által támogatott Nemzetiségi Óvodapedagógus Tanulmányi Ösztöndíj Program indult 2019-ben, amelyet jövő évtől a nemzetiségi tanítóképzés támogatására is kiterjesztenek. Az állam felismerte a nemzetiségi szervezetek figyelemfelhívása nyomán, hogy a nemzetiségi oktatás-nevelés és pedagógusképzés erőteljes fejlesztése nem halogatható tovább. 


\section{Irodalom}

Akimjak, Amantius (2013): Príprava učitel’ov pre primárne vzdelávanie na Pedagogickom inštitúte Juraja Páleša v minulosti a dnes. In: Chanasová, Zuzana \& Rončáková, Terézia Výchova a vzdelávanie ako nástroj (de)formovania hodnotového systému spoločnosti II. Zborník z konferencie, Trnava, Levoča, 2012, VERBUM - vydavatel'stvo KU, Ružomberok.

Bartal Alajos (1942): Az Esztergomi Érseki Római Katolikus Líceum és Tanitóképző Intézet története 1842-1942. Esztergom, Esztergomi Tanítóképző Intézet Igazgatósága.

Báthory Zoltán - Falus Iván (1997): Pedagógiai lexikon. II. kötet. Keraban Könyvkiadó, Budapest.

Donáth Péter (1998): Iskola és Politika. Az állami német nemzetiségi tanitóképzés magyarországi történetéhez 1919-1944. Trezor Kiadó, Budapest.

Donáth Péter (2008): A magyar müvelódés és a tanitóképzés történetéből 1868-1958. Trezor Kiadó, Budapest.

Donáth Péter (2018):„Kisemberek” helytállása: tanitóképzés baján a szerb megszállás alatt és nyomán 1918-1923. Trezor Kiadó, Budapest.

Drahos Ágoston és Kovács Péter (1991): A magyarországi nemzeti kisebbségek oktatásügye 1945-1990. Regio - Kisebbségtudományi Szemle, 2. évf., 2. sz. http://epa.oszk.hu/00 000/00 036/00 006/pdf/12.pdf Letöltés ideje: 2018. 11. 16.

Fazekasné Bartha Mária (1993): A szlovák tanítóképzés Esztergomban. Iskolakultúra, 3. évf., 8. sz. 97-98.

Föglein Gizella (2006): Etnikum és educatio: a magyarországi nemzetiségek és alsó fokú oktatásuk állami szabályozása, 1945-1985. Napvilág, Budapest. https://www.sulinet.hu/oroksegtar/data/magyarorszagi_nemzetisegek/ altalanos/etnikum_es_educatio/pages/000_konyveszeti_adatok.htm Letöltés ideje: 2018. 11. 16.

Gábris József (2000): Az esztergomi nevelőképzés krónikája II. (1959-1993). Az Esztergomi Tanító- és Óvónóképző Öregdiákjainak Egyesülete - Balassa Bálint Alapítvány a Tanító- és Óvónőképzésért, Esztergom.

Gunčaga, J. (2014): Teachers Institute in Spisska Kapitula. The first Teachers Institute in the area of Slovakia. History of Education \& Children's Literature, IX., 1. sz. 409-429.

https://www.researchgate.net/publication/297967 674_Teachers_Institute_in_S pisska_Kapitula_The_frst_Teachers_Institute_in_the_area_of_Slovakia Letöltés ideje: 2018. 11. 16.

Gunčaga, J. - Lang, L. (2017): Lehrerbildungsanstalten in Zipser Kapitel und Eger - ihre Bedeutung für Lehramtsstudium und Schulmathematik. Kultúrne deji- 
ny / Cultural History, 8. évf., 2. sz. 200-212.

https://www.researchgate.net/profile/Jan_Guncaga/publication/322 054571_Tea cher's_institutes_in_spisska_kapitula_and_eger_and_their_importance_for_m athematics_and_primary_education_teaching/links/

5b0c3a224585 157f871ca93b/Teachers-institutes-in-spisska-kapitula-and-egerand-their-importance-for-mathematics-and-primary-education-teaching.pdf Letöltés ideje: 2018. 11. 16.

Horváthné Farkas Éva (2012): Nemzetiségi képzés a Pázmány Péter Katolikus Egyetem Vitéz János Karán. Társadalmi Együttélés, 1. évf., 2. sz. 1-16.

Juhász Márta (2007): Die Ausbildung von deutschen Minderheitenpädagogen für die Grundschule an der Vitéz János Fakultät der Katholischen Péter-PázmányUniversität in Gran/Esztergom. Deutsch revital. Pädagogische Zeitschrift für das ungarndeutsche Bildungswesen, 4. évf., 4. sz. 93-96.

Juhász Márta (2018): A német nemzetiségi óvodapedagógus- és tanítóképzés helyzete napjainkban. In: Szőke-Milinte Enikő (szerk.): Pedagógiai küldetés - a küldetés pedagógiája. $\mathrm{PPKE}$, Budapest. 192-201.

Kiss József (1929): A magyar tanítóképzés statisztikai adatai. Magyar Tanitóképző, 42. évf., 1. sz. 22-35.

Kiss József (1929): A magyar tanítóképzés statisztikai adatai. Magyar Tanitóképző, 42. évf., 2. sz. 100-120.

Kiss József (1933): A magyar tanitóképzés reformgondolatai. Különnyomat a „Magyar Tanítóképző" 1933. évi 1-2. és 4. számából. Budapest.

Knipf-Komlósi, E. - Müller, M. (2018): Zwischen Vitalität und Aufgabe. Dynamische Aspekte in der Sprache der deutschen Minderheit in Ungarn. In: Jörg Meier (szerk.): Jahrbuch des Bundesinstituts für Kultur und Geschichte der Deutschen im östlichen Europa. Band 26 Sprache.de Gruyter Oldenbourg, München. $51-67$.

Kovács Krisztina - Grundig de Vazques, Katja (2011): A magyar és a német népiskolák és a néptanítói szaktudás fejlődése a történelem sorában. Képzés és Gyakorlat, 9. évf. 1-2. sz. 31-46.

Magyar Katolikus Lexikon. http://lexikon.katolikus.hu Letöltés ideje: 2018. 11. 17.

Márkus Éva (2006): A magyarországi németek oktatási helyzete. In: Bodó Edit (szerk.): „Kulcs Európához” Az idegen nyelvi és német nemzetiségi képzés a tanítóképzés elmúlt 15 évében. Budapest. 47-66. http://mek.oszk.hu/09100/09188/ Letöltés ideje: 2018. 11. 17.

Márkus Éva (2007): Kisebbségi oktatás - a magyarországi németek. Fórum. Társadalomtudományi Szemle, 1. évf., 4. sz. 111-127.

http://forumszemle.eu/2007/06/29/markus-eva-kisebbsegi-oktatas-amagyarorszagi-nemetek/ Letöltés ideje: 2018. 11. 17. 
Márkus Éva (2009): Az ELTE TÓFK magyar-német kéttannyelvủ tanító- és óvodapedagógus képzési programjai. In: Márkus Éva - Kovács Judit (szerk.): Kéttanyelvüség - pedagógusképzés, kutatás, oktatás. Az ELTE Tanító és Óvóképző Főiskolai Karán 2008. november 12-én megtartott konferencia előadásainak anyaga. ELTE Eötvös Kiadó, Budapest. 53-70.

Márkus, Éva (2016): Minderheiten in Ungarn und die Ausbildung von Minderheitenpädagogen an der ELTE TÓK. In: Ilse, V. -Suresch, I. -Winkler, M. (Hrsg.): Interkulturalität und Mehrsprachigkeit in den Schulen im Donauraum. Peter Lang, Frankfurt am Main. 81-92.

Márkus Éva (megj. alatt): A kétnyelvű nemzetiségi nevelés-oktatás az óvodában és az általános iskolában. In: Endrődy-Nagy Orsolya - Svraka Tamásné - F. Lassú Zsuzsa (szerk.): Elfogadás-befogadás? Inkluzív és multikulturális szemléletmód a pedagógiai gyakorlatban. Eötvös József Kiadó, Budapest.

Márkus Éva - M. Pintér Tibor (2019): Kezdetben vala... Szepeskáptalan. Az első német nemzetiségi tanítóképző intézet a történelmi Magyarország területén. Fórum Társadalomtudományi Szemle, 21. évf., 2. sz. 93-102.

Márkus, É. - Radvai, T. (2017): Die PädagogInnenausbildung für Kindergärten und Primarschulen der deutschen Minderheit in Ungarn an der ELTE TÓK. In: Philipp, H. -Ströbel, A. (Hrsg.): Deutsch in Mittel-, Ost- und Südosteuropa. Geschichtliche Grundlagen und aktuelle Einbettung. Beiträge zur 2. Jahrestagung des Forschungszentrums Deutsch in Mittel-, Ost- und Südosteuropa, Budapest, 1.3. Oktober 2015. Verlag Friedrich Pustet, Regensburg, 615-634. (= Forschungen zur deutschen Sprache in Mittel-, Ost- und Südosteuropa FzDiMOS, Band 5).

Mészáros István (1984): Népoktatásunk szervezeti-tartalmi átalakulása 1777-1830 között. Tankönyvkiadó, Budapest. (Pedagógiai közlemények 26.)

Mészáros István - Németh András - Pukánszky Béla (2004): Neveléstörténet. Bevezetés a pedagógia és az iskoláztatás történetébe. Osiris Kiadó, Budapest.

Molnár Béla (2007): A középfokú tanitóképzés története 1945-től felsőfokúvá válásáig. Budapest. Doktori disszertáció, ELTE PPK.

http://ppkteszt.elte.hu/file/Molnar_Bela_dissz.pdf Letöltés ideje: 2018. 11. 20.

M. Pintér Tibor (megj. alatt): Gondolatok az identitás nyelvi megnyilvánulásairól kisebbségi környezetben. In: Papp Ágnes Klára (szerk.): Kulturális, narratív, nyelvi identitás. KRE, Budapest.

Müller Márta (2015): A német nemzetiségi közoktatás és kimenete. In: Major Éva - Tóth Etelka (szerk.): Szakpedagógiai körkép. Idegennyelv-pedagógiai tanulmányok. ELTE, Budapest. 116-127.

Müller Márta (megj. alatt): Inklúzió a német nemzetiségi pedagógusképzésben. In: Endrődy-Nagy Orsolya - Svraka Tamásné - F. Lassú Zsuzsa (szerk.): Elfoga- 
dás-befogadás? Inkluzív és multikulturális szemléletmód a pedagógiai gyakorlatban. Eötvös József Kiadó, Budapest.

Nagy Péter Tibor (1993): Nemzetiség és oktatás a dualizmuskori Magyarországon. Educatio, 2. évf., 2. sz. 253-269.

Nagy Péter Tibor (2005): Az állami befolyás növekedése a magyarországi oktatásban 1867-1945. Iskolakultúra, 15. évf., 6-7. sz. 3-229.

Nagy Sándor (fószerk., 1979): Pedagógiai Lexikon. IV kötet. Akadémiai Kiadó, Budapest.

Németh András (1990): A magyar tanitóképzés története (1775-1975). Zsámbék. (=Főiskolai Füzetek Zsámbék 11.)

Neszt Judit (2014): A középfokú elemi iskolai tanitóképzők intézményrendszerének kiépülése és változásai 1828-tól 1945-ig. Doktori (Ph.D.) értekezés, Humán Tudományok Doktori Iskola, Debreceni Egyetem.

https://dea.lib.unideb.hu/dea/bitstream/handle/2437/213 836/Neszt_Judit_Ertek ezes.pdf?sequence=1\&isAllowed=y Letöltés ideje: 2018. 11. 20.

Olejnik, V. (2007): Učitelskýústav v Spišskej Kapitule. In: Lukáč, E. - Michalička, V. a kol.: História najstarších učitel'ských ústavov na Slovensku (1819-1945). Filozofická fakulta Prešovskej univerzity, Prešov. 357-390.

Panyik Ilona (1991): A Budapesti Tanitóképző Főiskola. Tankönyvkiadó - Budapesti Tanítóképző Főiskola, Budapest.

Pyrker, J. L. (1966): Mein Leben 1772-1847. Hgg. von Aladar Paul Czigler. Kommissionsverlag der Österreichischen Akademie der Wissenschaften, Wien.

Rácz Fodor Sándor (1993): A nemzetiségi tanítóképzés története (1870-1970). In: EfTKF Tudományos Közlemények 7. Eötvös Jüzsef Tanítóképző Főiskola, Baja. 129-141.

Šotter, V. (2012): Spišská Kapitula, alebo aj Malý Vatikán, či Slovenský Vatikán je bývalá samostatná obec vedla Spišského Podhradia, dnes je jeho súčastou., http://www.teraz.sk/zo-skol/pociatky-vzniku-ucitelskeho-ustavu/18 386clanok.html Letöltés ideje: 2018. 11. 20.

Szakál János (1934): A magyar tanitóképzés története. Budapest.

$A z$ intézmény múltja és jelene. Széchenyi István EgyetemApáczai Csere János Kar. https://ak.sze.hu/az-intezmeny-multja-es-jelene Letöltés ideje: 2018. 11. 20.

http://szarvasikronika.szarvasnet.hu/19_szam/19_04.htm Letöltés ideje: 2018. 11. 20.

Dejiny spišského biskupstva.

http://smalik.szm.com/htm/prace/spisskebiskupstvo.htm Letöltés ideje: 2018. 11. 20. 
http://keptar.oszk.hu Letöltés ideje: 2018. 11. 20.

1949. évi XX. törvény, a Magyar Népköztársaság alkotmánya.

http://www.rev.hu/sulinet45/szerviz/dokument/1949.evi3.htm Letöltés ideje: 2019. 04. 14.

1957. március 21. a művelődésügyi miniszter 859-8/1957. mm számú utasítása.

Az MDP nemzetiségpolitikai határozata az oktatásról - 1956

\section{0 years of German Language Primary School Teacher Education in Hungary}

This study aims to provide a short overview of the history of German language primary school teacher education and primary school teacher education for the German minority in Hungary. It explores the beginnings of teacher education in Hungary and the school life of the first independent teacher training school. Whilst exploring the internal life of this teacher training institution, it also presents the history of primary school teacher education for the German minority in Hungary in the 19th and 20th centuries. Using several national and international documents and studies and qualitative and quantitative analyses alike, the paper proves that primary school teacher education conducted in German played a pivotal role in the history of Hungarian primary school teacher education.

Keywords: German language primary school teacher education, primary school education for the minorities, state-run primary school teacher education in Hungary, Zipser Kapitel, education policy 